\title{
TURKEY ANALYSIS IN FRAMES ON CAUSES AND FINANCING QUALITY OF CURRENT ACCOUNT DEFICITS
}

\section{Ömer AKÇAYIR *}

* Süleyman Demirel Üniversitesi

E-mail: omerakcayir@sdu.edu.tr

Copyright (C) 2016 Ömer AKÇAYIR. This is an open access article distributed under the Eurasian Academy of Sciences License, which permits unrestricted use, distribution, and reproduction in any medium, provided the original work is properly cited.

\begin{abstract}
One of the most important macroeconomic problem has been undoubtedly explains the current account deficits (CADs) in economies gradually increased volume of trading and the diversity of international economic transactions in 21 th century. Turkey is also a country struggling with the CADs as about two thirds of the world economy. Another important concept as CADs continuity and a share of GDP and their causes is the knowledge of the deficit financing what it is highly reliable and robust. Because CADs is a flow variable and they will be financed in a way to be for sustainability. In this study, CADS which are continuing for fourteen years in Turkey has been investigated analytically the causes of CADs were examined in detail, their international status, types and quality of financing. The interpretation of a graphs obtained by utilizing different time series are made detailed analysis. According to all evaluations, the quality of financing of the CADs declined in recent years and CADs have increased the economic vulnerability in Turkey.
\end{abstract}

Keywords: Current Account Deficit, Financing Quality, International Comparison, Turkey Analysis

\section{CARİ AÇIKLARIN NEDENLERİ VE FİNANSMAN KALİTESİ ÇERÇEVESİNDE TÜRKIYYE ANALIZI}

\section{ÖZET}

Uluslararası ekonomik faaliyetlerin çeşitliğinin ve işlem hacminin giderek arttığı 21.YY ekonomilerinin en önemli makroekonomik sorunlardan birisi hiç şüphesiz cari açıklar olmuştur. Türkiye de dünya ekonomilerinin yaklaşık üçte ikisi gibi cari açıklarla mücadele eden bir ülkedir. Cari açıkların devamlılı̆̆ı ve GSYH içindeki payı ve verilen açıkların nedeni kadar önemli bir diğer kavram ise finansmanın ne derece güvenilir ve sağlam olduğu bilgisidir. Zira cari açıklar akım bir değişkendir ve sürdürülebilir olması için bir şekilde finanse edilecektir. Bu çalışmada, Türkiye'de ondört yıldır verilen cari açıkların nedenleri detaylı olarak incelenmiş, uluslararası konumu, finansmanın türleri ve kalitesi analitik olarak araştırılmıştır. Birçok farklı zaman serisinden yararlanılarak elde edilen grafiklerin yorumlanmasıyla, detaylı bir analiz 
yapılmıştır. Tüm değerlendirme sonuçlarına göre, Türkiye'de cari açıkların finansman kalitesi son yıllarda düşmüş ve cari açıklar ekonomik kırılganlığı artırmıştır.

Anahtar Kelimeler: Cari Açık, Finansman Kalitesi, Uluslararası Karşılaştırma, Türkiye Analizi 


\section{GíRiş}

Cari işlemler hesab1, ödemeler bilançosunun en mühim kalemi olup, bu kalemin göstermiş olduğu denge ya da dengesizlikler ülkenin makroekonomik durumunu analiz edebilmek için dikkatle takip edilmelidir. Bir ya da birkaç dönemde ortaya çıkan cari dengesizlikler genellikle çok büyük sorunlar teşkil etmez iken, bu dengesizliklerin kronikleşerek uzun dönemler halinde devam etmesi bazı yapısal sorunlara işaret etmektedir. On dört yıldır kesintisiz olarak cari açık veren Türkiye için bu açıkların kronikleştiği net olarak ifade edilebilir. Bu açıdan cari açıkların nedenleri çok doğru analiz edilmelidir ki, doğru tedavi uygulanarak yapisal sorunlar giderilebilsin. Aksi takdirde bu sorun daha ciddi boyutlu makroekonomik sorunlara yol açacaktır. Bu açıdan bu çalışmada, Türkiye'nin cari açık sorununun sebepleri ve finansmanının kalitesi anlamında detaylı bir analiz yapılmaktadır. Cari açık sorunu sadece Türkiye'ye ait bir sorun olmayıp ABD, İngiltere ve Fransa gibi birçok gelişmiş ülkenin de mücadele ettiği önemli bir sorundur. Bu durum, bize sürdürülebilirlik kavramının ve bu açığı finanse eden kaynakların kalitesini araştırmaya itmektedir. Çalışmada, Türkiye'nin cari işlemler hesabının geçmişi ve bugünü ele alınarak, sorunun kaynakları ve bunu finanse eden dengeleyici unsurların kalitesi araştırılmaktadır.

\section{Türkiye'de Cari İşlemler Açığı ve Gelişimi}

Türkiye'de cari denge hareketlerini 1980 sonrası için incelemek gerekirse ortalama onar yıllık guruplar halinde değerlendirmek doğru bir yaklaşım olacaktır. Zira Türkiye'de cari işlemler hesabı dengesi, 1980-1990 yılları arasında küçük sapmalar göstermekte, 1990-2001 yılları arasında çoğunlukla siyasi ve ekonomik istikrarsızlığı yansıtan yapısal sorunlarında etkisiyle dış açık eğilimli daha belirgin hareketler sergilemektedir. 2002 sonrasına ait cari denge hareketleri incelendiğinde ise bambaşka bir tablo karşımıza çıkmaktadır. Küresel kriz etkilerinin hissedildiği 2009 yılı hariç büyük oranlı bir artış trendi net olarak göze çarpmaktadır.

Cari açıkların müstakil olarak rakamsal ifadesinden ziyade ekonominin büyüklüğü nispetinde oranı daha gerçekçi bir gösterimdir. Örneğin ABD’nin 2014 yılı itibariyle cari açığ 1 yaklaşı 110 Milyar USD (\$) iken, aynı dönemde Türkiye'de cari açık yaklaşık 46 Milyar USD (\$) civarındadır. Fakat ekonominin büyüklüğü bazında değerlendirildiğinde cari açık/GSYH oranı, ABD'de -\%2.4 iken Türkiye'de -\%5.8 olduğu görülmektedir. Cari açıkların sürdürülebilirliği perspektifinde, cari açık/GSYH rasyosu tek başına kesin bir ekonomik kriz işareti olmamakla birlikte, oldukça önemli bir göstergedir.

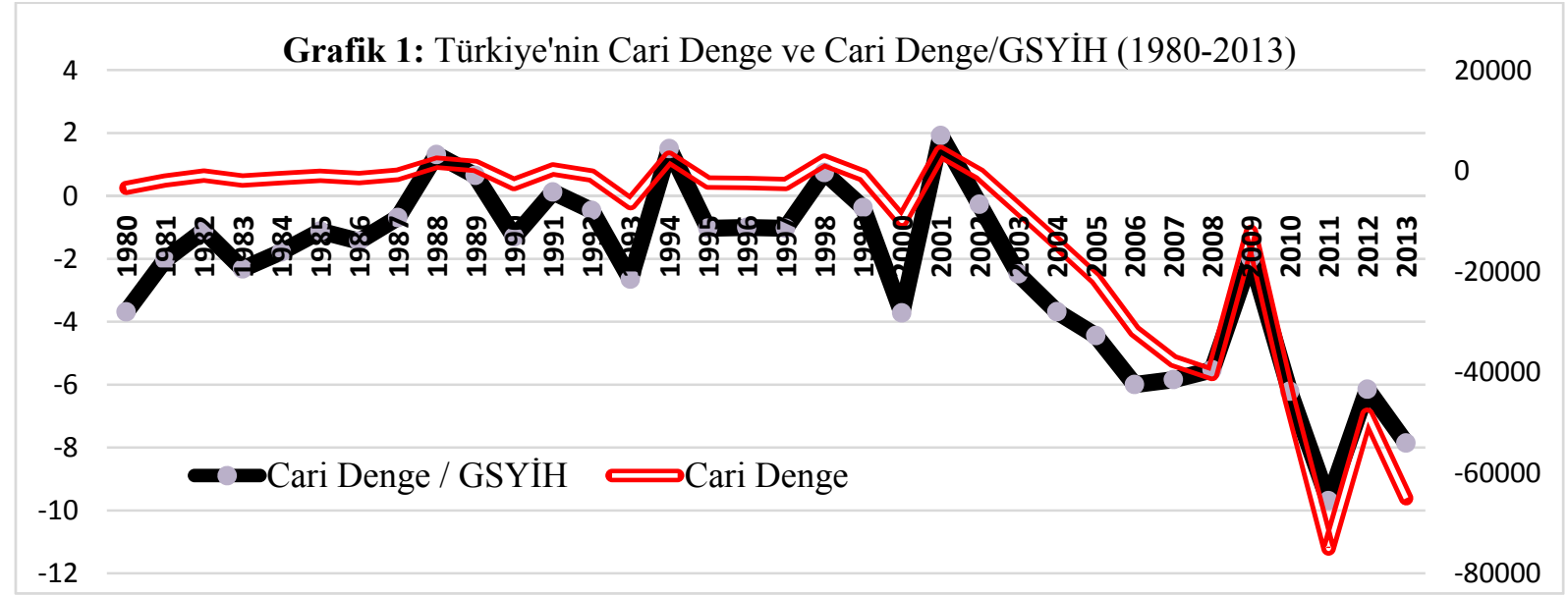

Kaynak: http://unctadstat.unctad.org 
Cari açık/GSYH oranı alt ve üst sınırının ne olması gerektiği ile ilgili çok net bir şey söylemek mümkün olmamaktadır. Fakat bu konuda genel temayül, bu oranın $\pm \% 4$ ya da $\pm \% 5$ seviyelerinin eşik olarak görülmesi yönündedir. (Yalçıner,2012:147) Türkiye'de, Cari açık/GSYH oranı 2003-2014 yılları için sırasıyla -2,49 -3,62 -4,44 -6,02 -5,85 -5,53 -1,97 -6,21 -9,69 -6,15 -7,94 -6,4 şeklindedir. Türkiye'de Cari Açık/GSYH oranlarının, uzun süredir eşik olarak görülen değerin üzerinde seyrettiği görülmektedir.

\subsection{Türkiye'de Cari İşlemler Açı̆̆ıın Sebepleri}

Ödemeler bilançosu açıkları veya spesifik olarak cari açıklar, ulusal ekonomi üzerinde birçok olumsuz etki bırakmaktadır. Cari işlemler hesabı açık veren ülkelerin, diğer ülkelere kıyasla dişsal şoklara daha açık ya da savunmasız olduğu bilinmektedir. Cari açıklar, ülkelerin birçok makroekonomik değişkeni üzerinde baskı oluşturmakta, özellikle döviz rezervlerini tüketme tehlikesi ile karşı karşıya bırakmaktadır. Dolayısıyla bu sorunlarla karşılaşan ülkeler en reel çözüm yöntemi olarak ihracatı artırıcı ve ithalatı azaltıcı politikalar yürüterek ülkeye döviz kazandırabilecek ve döviz çıkışına önleyecek stratejiler üzerinde yoğunlaşmak zorundadırlar. (Kaymakçı vd. 2007: 48)

Cari denge önemli bir makroekonomik gösterge olup, neredeyse tüm ekonomi politikalarının yürütülmesinde temel bir değişkendir. Bu sebeple cari açıklarının nedenleri çok iyi analiz edilip, doğru tedbir ve politikalar ile bu sorunlar giderilmeye çalışılmalıdır. Cari işlemler hesabı birçok ülkede açık verirken, bir kısım ülkede fazla da verebilmektedir. Küresel düzeyde erişilebilen 2013 yılına ait olarak ödemeler bilançosu verilerine ${ }^{1}$ göre 185 ülkenin 62'si cari fazla verirken, 123 ülke ise cari açık vermektedir. Her iki dengesizlik durumu da bir takım riskleri bünyesinde barındırmaktadır. Fakat cari açıklarının daha sık rastlanan bir durum olması ve Türkiye'nin de bu sorunla karşı karşıya kalması sebebiyle cari açıklara neden olan durumlar birçok kitap ve akademik çalışmalarda detaylı olarak incelenmiştir. Her ülke için cari açıklara neden olan durumlar farklı olabilmekle birlikte, bu çalışmada Türkiye özelinde cari açık sorununun nedenleri irdelenecektir.

Türkiye'de cari açı̆̆ının nedenleri kapsamında birçok madde sayılabilir. Fakat bazı kavramları bazı başlıklar altında incelemek konunun daha sade ve anlaşılır olması açısından önemli görüldüğünden sınırlı düzeyde başlık altında incelenmiştir. Cari işlemler açıklarına neden olan durumları yapısal sorunlar, konjonktürel dalgalanma sorunları, geçici sorunlar ve nihayet olağan dışı ya da rassal bazı sorunlar olarak değerlendirip böyle bir sınıflandırmaya tabi tutmak mümkün olsa da bu çalışmada böyle sınıflandırma yapılmamıştır.

\subsubsection{Dış Ticaret Açı̆̆ı}

Ülkeler arasında birçok konuda ekonomik ilişki bulunmakla birlikte dış ticaret işlemleri uluslararası ekonomik ilişkilerin en eski ve hiç değişmeyen unsuru olmuştur. Ülkelerin birbirleri ile dış ticaret ilişkisi içerisinden bulunmasının başta dünyadaki zenginlik kaynaklarının ve potansiyel ekonomik kaynakların dağılımındaki dengesizlik olmak üzere, karlılık ve ürün çeşitliliği gibi birçok nedeni bulunmaktadır. Bu sebeplerle dış ticaret işlemleri, ödemeler bilançosunda sahip olduğu hacim ve potansiyeli gereği çok önemli bir yer tutmaktadır. Otonom bir kalem olan diş ticaret hesabı (mal ve hizmet dengesi) genel olarak cari dengesizliklerin (açık ya da fazla) en temel belirleyicisidir.

Türkiye'nin ihracat, ithalat ve hizmet gelir giderleri incelendiğinde, cari açıkların kronikleşmesinde görünen en bariz neden olarak net ihracatın azalması yani ithalatın ihracattan daha hızlı artması durumu söylenebilir. (Grafik 2.) Bir diğer açıdan mal dengesinin yıllara göre

\footnotetext{
${ }^{1} \mathrm{http} / /$ unctad.org/en/Pages/Statistics.aspx
} 
değişim hareketleri cari dengenin hareketleri ile küçük farklar dışında birebir benzemektedir. $\mathrm{Bu}$ durum bize cari dengenin en önemli belirleyicisinin mal dengesi olduğunun bir göstergesidir. Hizmet dengesine bakıldığında ise, cari denge ile ters yönlü ve kısmen simetrik bir tablo ortaya çıkmaktadır. Bu durum hizmet dengesinin mal dengesi ile ilişkili olmak üzere mal dengesinin verdiği açıkların hizmet dengesi ile bir miktar finanse edildiğini (kapatıldığının) ortaya koymaktadır. (Grafik 3.)

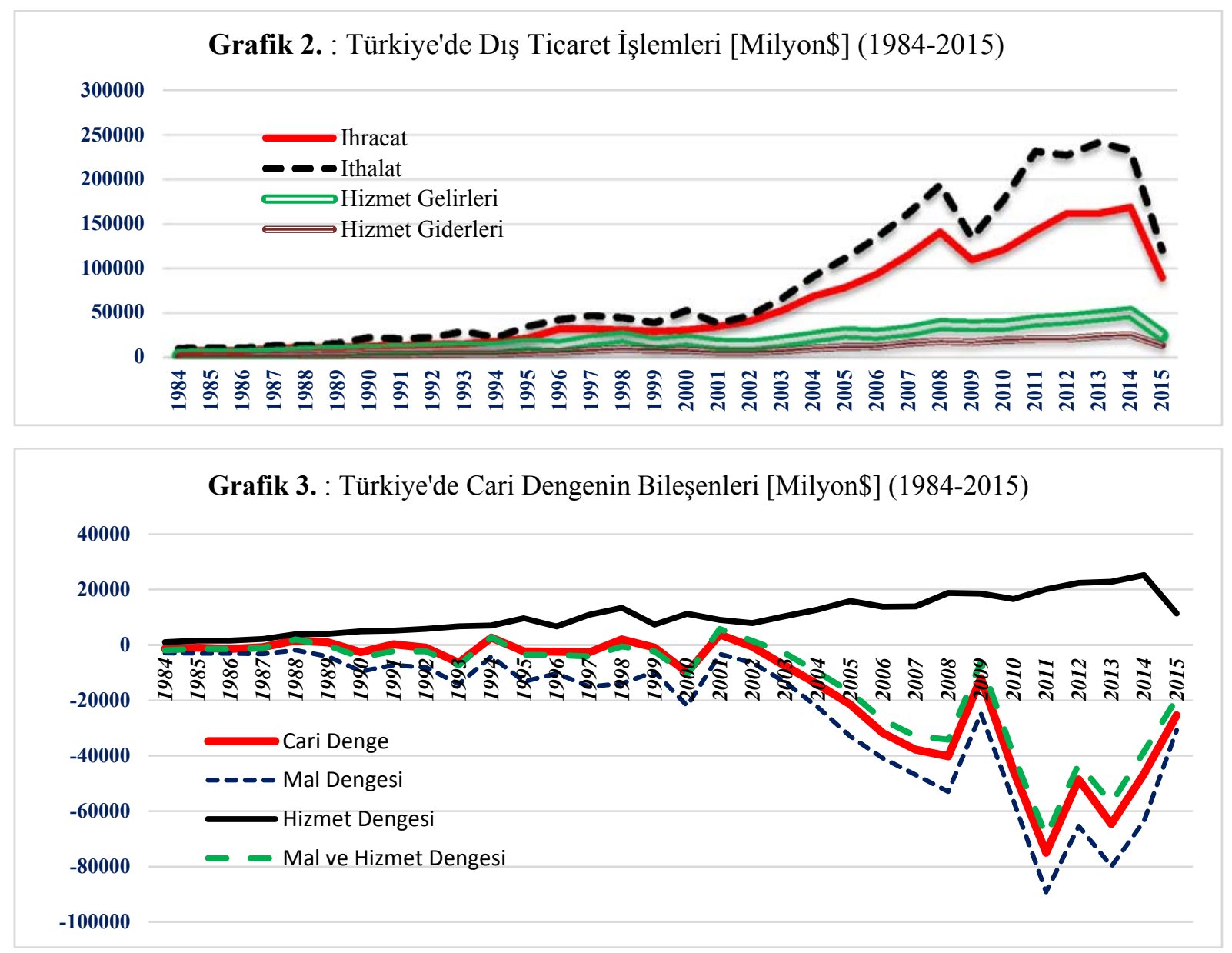

Kaynak: http://evds.tcmb.gov.tr/ (2015 Yılı Temmuz Ayı İtibariyle Açılanan Rakamdır.)

Türkiye, en kaba ifadesi ile son 13 yıldır ürettiğinden daha fazlasını tüketen bir ülkedir. 1980'li yılların ikinci yarısından itibaren ithalat daima ihracatı geçmiş, fakat 2002 yılından itibaren bu fark iyice açılmıştır. İhracatın ithalatı karşılama oranı diye de ifade edebileceğimiz ihracat/ithalat oranı son 13 yılda ortalama olarak yaklaşık $\% 73$ civarında gerçekleşmiştir. (Grafik 4.) Açılan bu farkın nedenleri dışa bağımlılık gereği enerji ithalatı, ara malı ithalatı, katma değeri düşük mal ihracatı ve katma değeri yüksek mal ithalatı gibi birçok madde ile kendi içinde ayrı olarak değerlendirilecek bir konudur. 


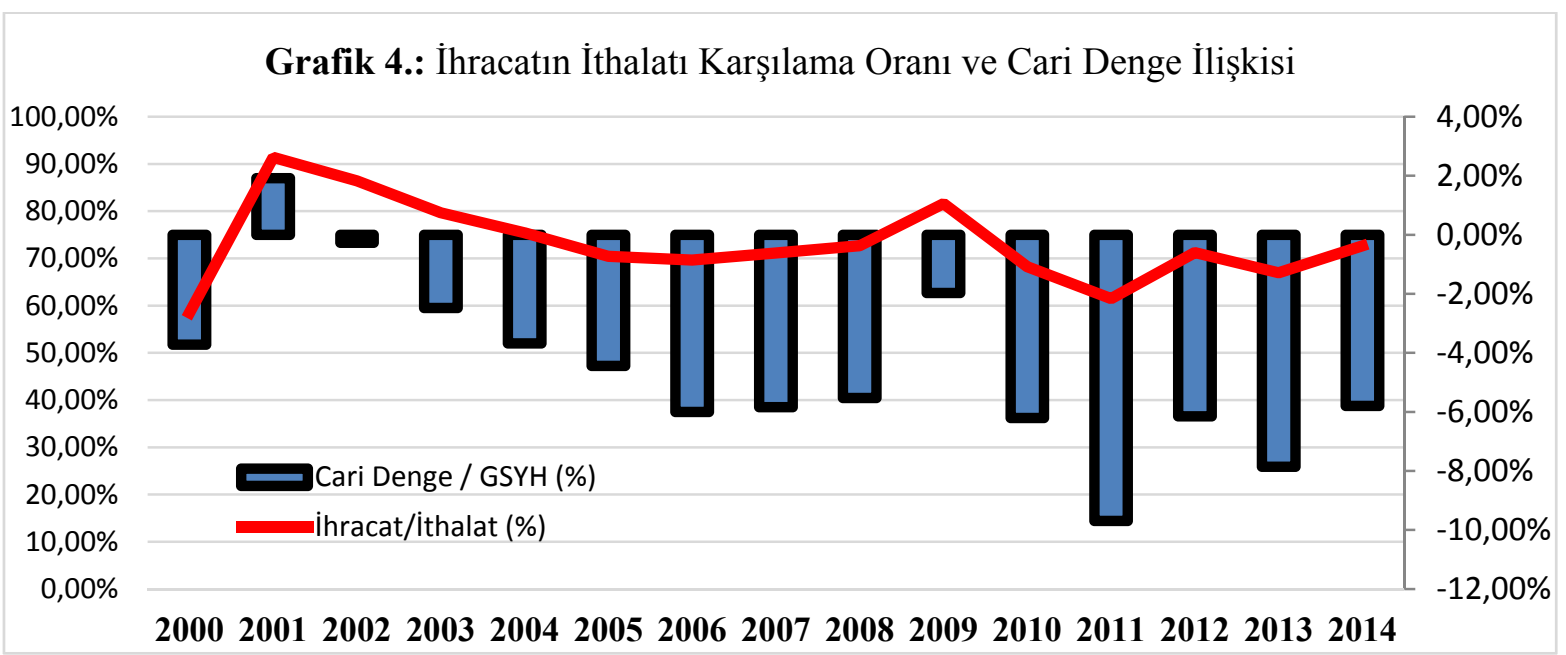

Kaynak: http://evds.tcmb.gov.tr/

\subsubsection{Yurtiçi Yatırımlar ve İç Tasarrufların Yetersizliği}

Ülkelerin refah düzeyinin artmasına neden olan ekonomik büyüme mutlaka toplam üretim artışı ile gerçekleşebilirken, üretim artışı ise yurtiçi yatırımlar sayesinde mümkün olabilmektedir. Uzun vadeli yüksek oranlı sürdürülebilir büyüme için yatırım/GSYH rasyosunun en az \%20 olması gerektiği birçok çalışmada vurgulanmaktadır. Yurtiçi yatırımların nasıl finanse edildiği bilgisi ise, sürdürülebilir büyüme için en önemli kıstaslardan birisidir. Türkiye'de 2001 krizi öncesine kadar kamu açıklarının bankacılık sistemince finanse edilmesi sonucu yükselen reel faizler özel sektörü dışlamış ve özel kesim yatırımlarını azaltmıştır. 2002 sonrasında ise sıkı maliye politikaları ile bu sorunlar giderilmiş ve bankacılık sistemi özel sektörü ve hanehalklarını finanse etmiştir. Bu durum özel sektör yatırımlarını artırmıştır. (Kalkınma Bakanlığı,2014)

Bankalar, en dar tanımıyla tasarruf sahiplerinden topladıkları mevduatları fon ihtiyacı olanlara kredi olarak kullandıran finansal işletmelerdir. Bankaya giren her mevduat zorunlu karşılık oranı ayrıldıktan sonra kredi olarak kullandırılabilir. Buna bankaların kaydi para yaratma fonksiyonu denir. $\mathrm{O}$ halde kredi miktarının artması nihayetinde mevduatların yani toplam tasarruf oranlarının artması ile mümkündür. Şayet ülkedeki yurtiçi tasarruf oranı yetmez ise, yurtdışı tasarruflar devreye girmektedir. Bu durum ise ülkenin borç yükünü ve kırılganlığı artırmaktadır.

Massetme (toplam harcama) yaklaşımına göre yatırım tasarruf farkı cari dengeyi vermektedir. Bu açıdan tasarruf açığı da denilen bu farkın kapatılması cari dengenin sağlanması açısından oldukça önem arz etmektedir. Türkiye'de yatırım oranı \%15 ile \%25 arasında değişirken tasarruf oranı son yıllarda sürekli olarak düşmekte ve son üç yıl itibariyle sırasıyla, $\% 11,6$, \%12,76 ve \%13,35 civarında gerçekleşmiştir. Yani yatırımlar genel olarak tasarruflardan hep yüksek olmuştur. Bu sebeple tasarruf açığı oluşmaktadır. Diğer ülkeler için tasarruf oranı 2013 yılı itibariyle Çin'de \%50, Hindistan'da \%38 ve gelişmekte olan ülkelerde ortalama \%33'tür. (AA, 30.11.2013) Yatırımlara nispeten oldukça düşük olduğu herkesçe kabul edilen yurtiçi tasarruf oranı, finansal derinliğin oluşmaması nedeniyle yatırımların finansmanında yetersiz kaldığından dış borçlanmayı zorunlu kılmaktadır. Türkiye gibi gelişmekte olan ülkelerin büyüme hedefleri çerçevesinde tasarruf oranlarının rolü oldukça önem arz etmektedir. Türkiye'nin hedeflediği her ek birim büyüme oranının cari açıkları $\operatorname{artırdığ~genel~bir~kabul~olmuştur.~Bu~durum~ise,~borçlanma,~büyüme~ve~cari~açıkların~}$ 
sürdürülebilirliği adına riskleri ve finansal kırılganlığı artırmaktadır. (Kalkınma Bakanlığg, 2014)

Türkiye'nin 2002 sonrası için yurtiçi tasarruf oranlarının (GSYH oranı \%) değişimi ile cari açıkların (GSYH oranı \%) değişimi karşılaştırıldığında, iniş ve çıkış trendlerindeki benzerlikleri net olarak göze çarpmaktadır. (Grafik 5.) O halde Türkiye'de cari açıkların en temel nedenleri olarak iç tasarruf oranlarının yetersizliğini rahatlıkla sayabiliriz.

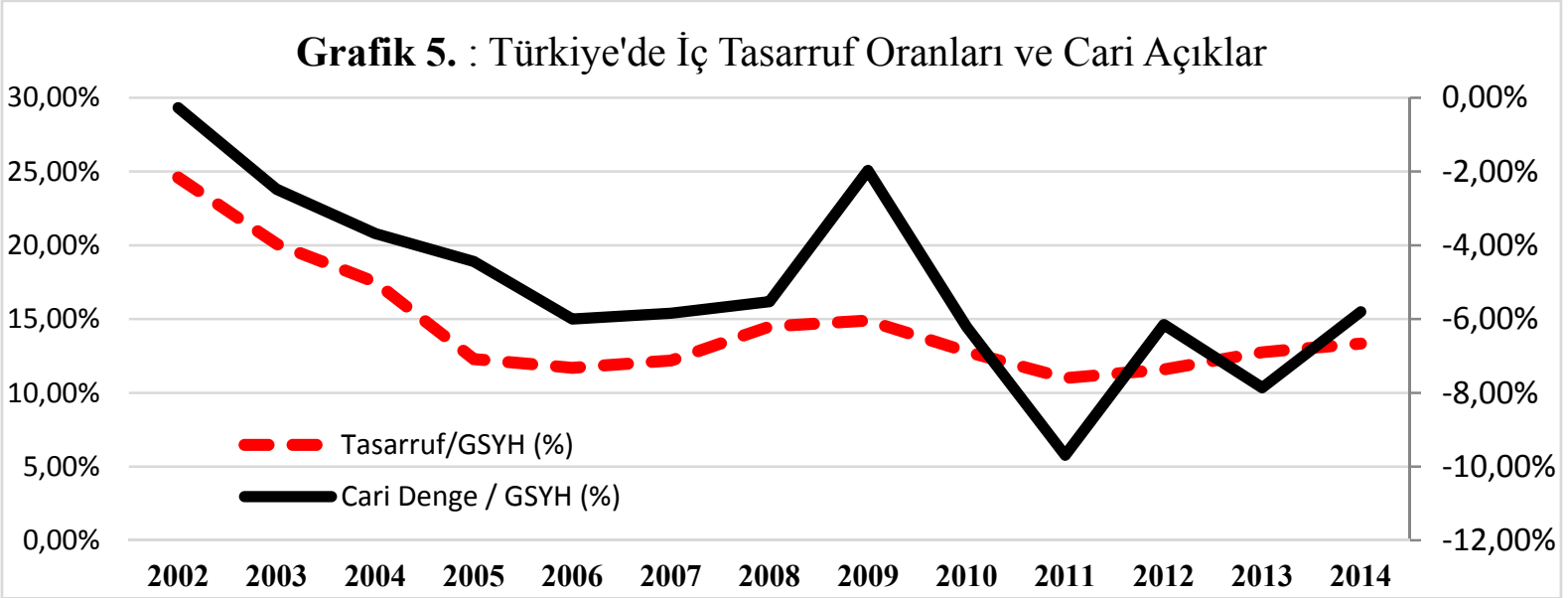

Kaynak: TCMB, http://www.imf.org/, http://www.mahfiegilmez.com/

\subsubsection{Ekonomik Büyüme Dinamikleri}

Bir önceki başlıkta bahsedilen ifadelerin tamamı esasında ekonomik büyüme olgusu için de geçerli olup, anlatılanlara ek olarak bazı dinamiklerden de bahsetmek gerekmektedir. Bütün ülkeler için ekonomik büyüme oranına ait veriler oldukça önem arz etmektedir. Zira büyüme rakamları ülkenin gelişimi ya da kriz göstergeleri anlamında en belirgin dinamiğidir. Diğer taraftan Türkiye gibi gelişmekte olan ülkelerin gelişmiş ülkeler sınıfında yer alabilmesi için uzun vadeli bir ekonomik büyüme trendi yakalaması gerekmektedir. Nitekim Türkiye'nin bütün ekonomik hedef ve politikaları sürdürülebilir yüksek büyüme üzerine odaklanmaktadır. 2009 küresel krizi sonrasında çok iyi bir büyüme potansiyeli yakalayan Türkiye, yüksek olarak değerlendirilebilecek büyüme rakamlarını birçok nedenden dolayı uzun vadeli olarak sürdürememiş, büyüme oranları potansiyelin altında kalmıştır.

Türkiye'nin uzun soluklu ekonomik büyüme hızı yakalayabilmesinin önünde birçok yapısal sorun bulunduğu net olarak söylenebilmektedir. Başta sayaşacağımız enerji, hammadde ve ara malında dışa olan bağımlılığına ek olarak, küresel kriz sonrası likidite bolluğu ile sahip olduğu büyüme potansiyellerinin yeteri düzeyde verimli olarak değerlendirememesi, son dört yıldır orta gelir tuzağına takılıp kalması ve borçlanmanın artmasına mukabil dönemler arası bütçe kısıtı kapsamında bunların verimli yatırımlara dönüştürülememiş olması gibi birçok nedenden de bahsetmek mümkündür. (Kalkınma Bakanlığı, 2014) Türkiye'de 2001 yıl1 öncesinde yüksek büyüme çabaları kamu açıklarını artırırken 2001 krizi sonrasında bu çabanın etkisi cari açıklara yönelmiştir. Türkiye'nin 2000'li yıllarda elde ettiği büyüme oranları ile cari işlemler açığının gösterildiği grafik incelendiğinde, ikisi arasında ters ve simetrik bir ilişki olduğunu görmek mümkündür. Bu durum bize Türkiye'de ekonomik büyümenin, yurtiçi yatırım ve tasarruf oranlarının örtüşmemesi (tasarruf açığı) nedeniyle doğrudan cari açı̆̆ artırdığını kanıtlamaktadır. (Grafik 6.) 


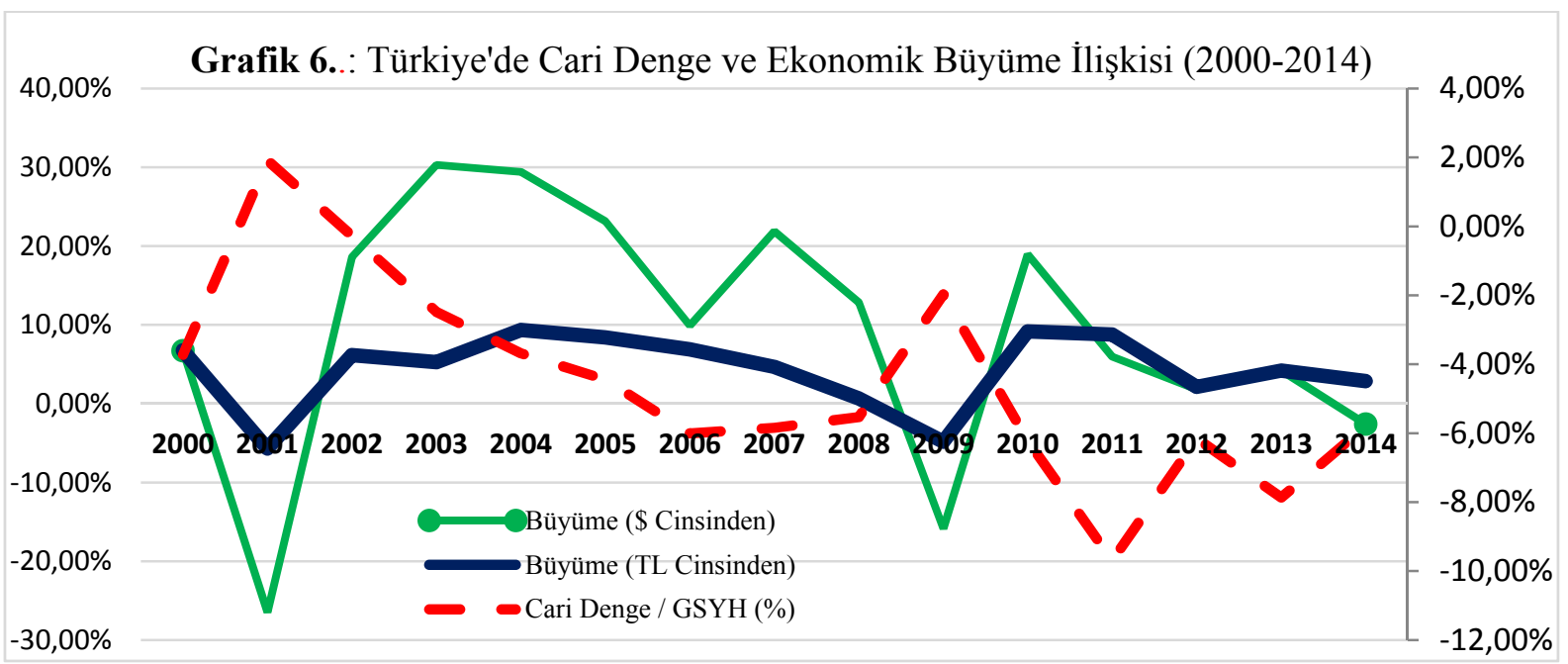

Kaynak: http://evds.tcmb.gov.tr/, TÜIK, Kalkınma Bakanlığı

\subsubsection{Bankacılık Sektörü Kredi Genişlemesi}

Türkiye' de birçok makroekonomik değişken gibi bankacılık sektörü yurtiçi kredi hacmi de 2001 krizi sonrasında yeni bir büyüme trendine girmiştir. Fakat bu artış öylesine yüksek oranlı olmuştur ki, TCMB verilerine göre TL bazında 2014 yılındaki kredi hacmi 2002 yılına göre yaklaşık 32 kat artmıştır. Bu ciddi artışa karşılık mevduatlar aynı dönemde yaklaşık sadece 7,5 kat artmıştır. (Grafik 7.) Bu durum, kredilerin yetersiz olan yurtiçi tasarruflar ile finanse edilemediğinin ve ek olarak yurtdışı tasarruflarının da kullanıldığının (borçlanıldığının) bir göstergesidir.

Özellikle 2009 küresel krizi sonrası ABD Merkez Bankası'nın (FED) genişletici para politikaları, Türkiye gibi gelişmekte olan birçok ülkede sermaye hareketi yoluyla likidite bolluğuna neden olmuştur. $\mathrm{Bu}$ bolluk dış borçlanmayı kolaylaştırmış ve borçlanma maliyetlerini görece azaltmıştır. Uzun süredir tasarruf açığı olan Türkiye için iyi bir firsat olan bu durum, kredi hacminde dramatik bir artışa neden olmuştur. Bir diğer açıdan, kredi hacmi artış1 ya da kredi genişlemesi, kredi tahsis edilen gerçek ya da tüzel kişi için ek bir satın alma gücü sunmaktadır. Hem yatırım hem de tüketim talebini tetikleyen bu satın alma gücü ise, nihayetinde tüketim harcamalarına dönüşmektedir. Tamamının yurtiçi piyasalardan karşılanması mümkün olmayan bu talep artışı, ithalatı tetiklemekte ve net ihracatı azaltmaktadır. Nihai olarak ise bu durum, cari açıkları artırmaktadır. (Kalkınma Bakanlığı, 2014)

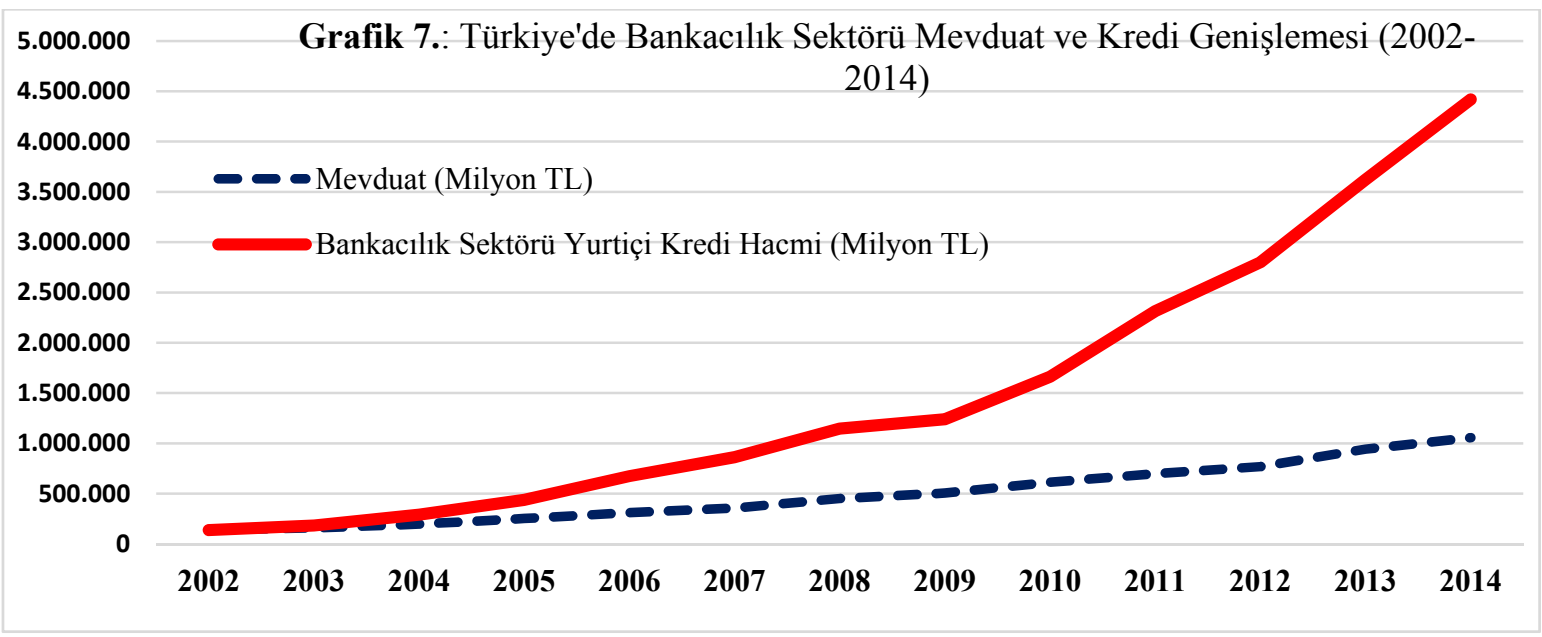


Kaynak : TBB, http://evds.tcmb.gov.tr/

Ülkelere dışarıdan giren sermaye birçok açıdan ülkeye katkı sunmakla birlikte sermayenin uzun ya da kısa vadeli olması sermayenin kalıcı (yapısal) ya da geçici katkısı açısından oldukça önemlidir. Türkiye'ye gelen sermaye küresel krize kadar 2003-2009 döneminde uzun vadeli yatırımlar (DYY ya da uzun vadeli portföyler) iken, kriz sonrasında bollaşan likidite ve değeri yükselen ulusal para sebebiyle büyük oranda kısa vadeli olmuştur. Bunun sonucu olarak kredi hacmi çok hızlı şekilde artmıştır. Ayrıca bu durum cari açıkların finansmanı açısından sürdürülebilirliğin riskini de dışa bağımlılık açısından artırmaktadır. (Kalkınma Bakanlığı, 2014) Bir diğer açıdan 2002 sonrasında \%60'a varan oranlarda kredi genişlemesi gerçekleşmiş; bu genişleme karşısında ise cari açıklar negatif yönde büyümeye devam etmiştir. 2011 yılı sonrasında ise, kredi genişleme oranının daha küçük yüzdelerde gerçekleştiği görülmekte, cari denge/GSYH oranı da bu duruma karşılık daha az bir tepki göstermektedir. $\mathrm{Bu}$ durumu, 2011 yılı sonlarına doğru BDDK ve TCMB'nin kredi genişlemesine dönük yürüttüğü politikaların etkisi olarak değerlendirmek mümkündür. (Grafik 8.)

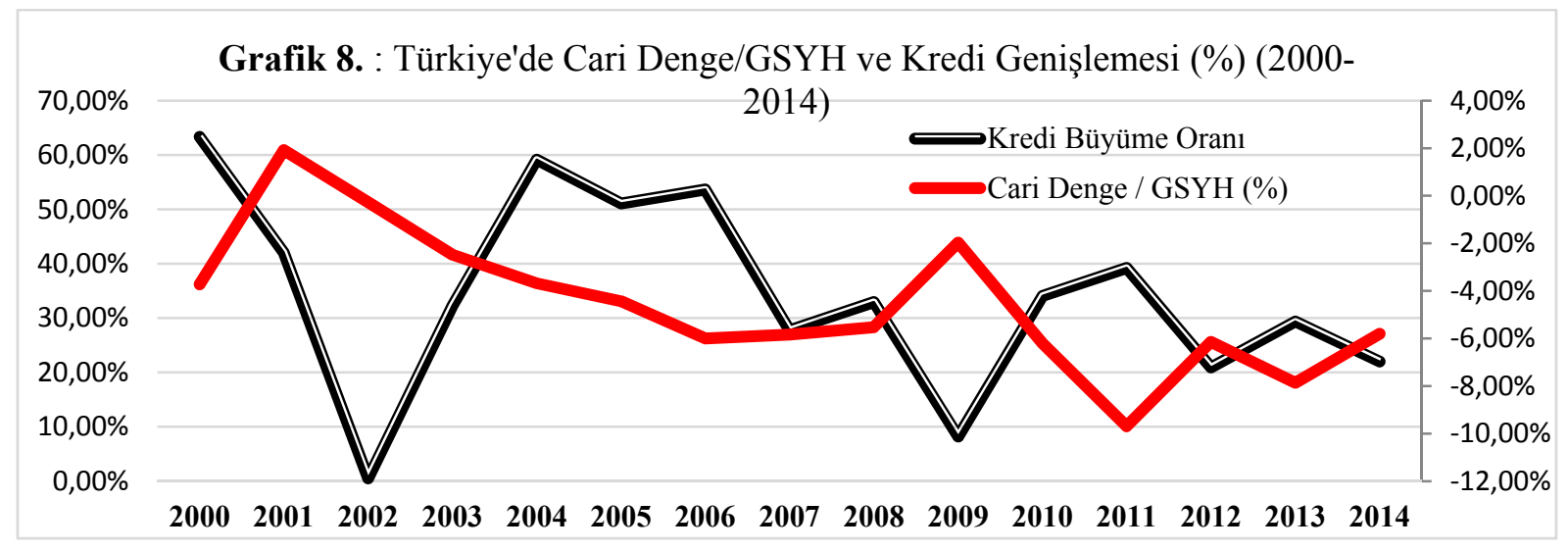

Kaynak: http://evds.tcmb.gov.tr/, TBB

\subsubsection{DYY ve Portföy Yatırımların Kar Transferleri}

Ödemeler bilançosunda, doğrudan yabancı yatırımlar ve portföy yatırımları cari açıkları finanse eden denkleştirici bir işlem olup sermaye ve finans hesabına kaydedilirken, bunlardan elde edilen faiz ve kar payı gibi gelirler cari işlemler hesabının gelir dengesi kalemine kaydedilmektedir. (Seyidoğlu,2009:319) Ülke içinde faaliyette bulunan yabancıların kendi ülkelerine transfer ettikleri kar, temettü ve faiz gelirleri, bahsi geçen ülke için gider olarak, tam tersi durum olarak yerleşiklerin yurtdışı işlemlerinden elde ettiği gelir transferleri ise gelir olarak kaydedilir. (Yalçıner,2012:131)

Türkiye 2001 küresel krizi sonrasında yabancı yatırımcılar için birçok ülkeye kıyasla yüksek karlılık ve düşük risk anlamında cazip bir ülke haline gelmiştir. Türkiye'de özelleştirmelerin de katkısıyla 2009 yılına kadar doğrudan yabancı yatırımlar ve uzun vadeli portföy yatırımları ciddi oranda bir paya sahip iken; 2009 küresel krizi sonrasında portföy yatırımları genellikle kısa vadeli yatırım türleri ağırlıklı olarak bir yapısal değişime uğramıştır. $\mathrm{Bu}$ yatırımlardan elde edilen faiz ve kar payı transferleri cari işlemler hesabına gider olarak kaydedildiğinden, cari açıkların artmasına bir miktar negatif bir katkısı bulunmaktadır. (Grafik 9.) 


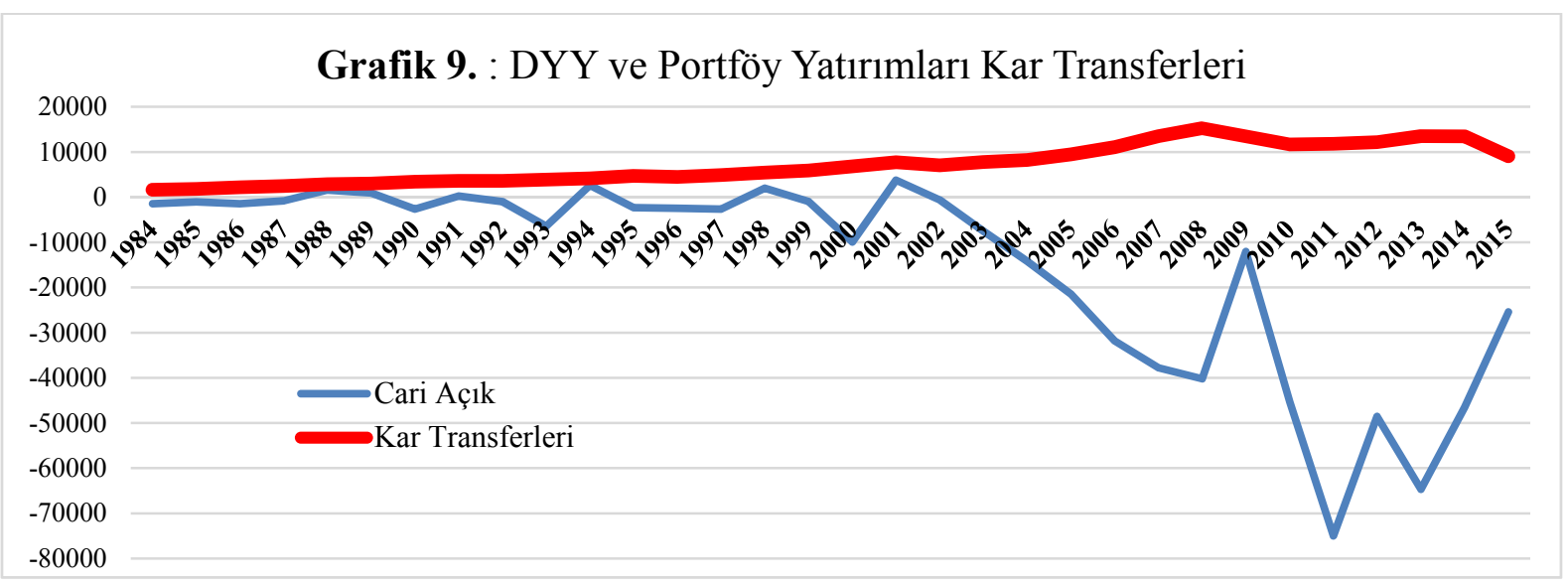

Kaynak: http://evds.tcmb.gov.tr/

\subsubsection{Hammadde ve Enerjide Dışa Bağımlılık}

Ülkelerin ekonomik anlamda en önemli hedefi büyümek, milli gelirini artırmak ve toplumsal refah düzeyini bir adım öteye taşımaktır. Büyümenin en kilit kavramı ise mal ya da hizmet üretmektir. Günümüzde hemen hemen bütün ürünlerin üretimi için en temel girdiler enerji özelinde petrol ve doğalgazdır. Alternatif enerji kaynaklarının tüm çabalara rağmen yeteri düzeyde işlerlik kazanamadığı Türkiye'de enerjide dışa olan bağımlılık daha da artmaktadır. Petrol kaynaklarına sahip olan ülkeler için enerji daha ucuz ve erişilebilirken, Türkiye gibi enerjide (petrol, doğalgaz vs.) dışa bağımlı ülkeler için büyük oranlı bir girdi ithali anlamına gelmektedir. Yani, 1 USD (\$) değerinde ihracat yapabilmenin yolu, kabaca en az 0,3-0,4 USD (\$) değerinde enerji ithalinden geçmektedir. Enerji ithalatının toplam ithalat içindeki payı incelendiğinde bu oranın da 2004 yılı sonrasında büyüme oranına paralel olarak artığ1 görülmektedir. (Grafik 10.)

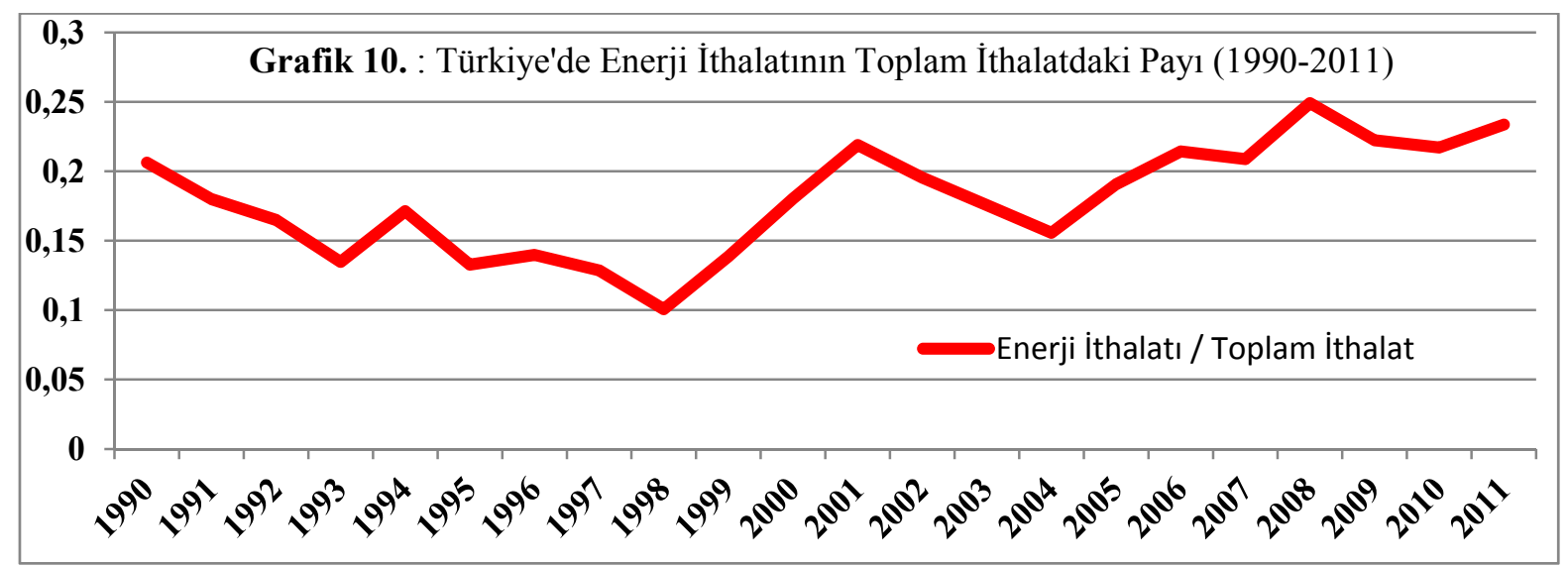

Kaynak : http://evds.tcmb.gov.tr/, TÜIK

Bir başka açıdan ise, bir ürünün üretimi için enerji ihtiyacı dışında, hammadde, elektronik ya da mekanik bir parça ithalatından da bahsedilebilir. Özellikle çok uluslu firmalar araba, elektronik vs. gibi ürünlerin üretiminde çok farklı ülkelerde doğrudan yabancı yatırım kanalı ile ürettiği parçaları firma içi ya da bağımsız olarak firma dişı ithalat olarak temin etmektedir. Örneğin, bir Alman firmasının ürettiği bir otomobilin, motoru Almanya'dan, lastikleri Brezilya'dan, kaportası İtalya'dan, döşemeleri Türkiye'den ve plastik malzemeleri Çin'den ithal edilmektedir. Bir başka örnek olarak, yerli üretim olarak bildiğimiz birçok markanın akıllı (smart) telefon üretiminde, katma değeri yüksek olan en önemli parçaları Çin'den ithal edilmektedir. Değeri, yaklaşık 750 € olan telefonun rekabet ed(ebil)ip satabilmesi 
yoluyla kasaya girecek olan paranın muhtemelen 500£'si ithalat yoluyla mümkündür. Bu gibi sebeplerden dolayı enerji ve hammaddeyi de içine alan ara malı ithalatının toplam ithalata oranı son yıllarda yaklaşık \% 70'in üzerinde seyretmektedir. (TİM, 2014:105)

Türkiye'de cari denge üzerinde en büyük baskıyı oluşturan ithalatın bileşenlerinin irdelenmesi yapısal olarak sorunun tespiti ve çözümü açısından son derece önemlidir. Türkiye'de 1992'den 2015 yılına kadar toplam ithalat içinde en büyük pay \% 58-78 aralığında dalgalanan aramalı ithalatına aittir. Sermaye mallarının ithalatının toplam ithalat içindeki payı uzun dönemde (\%28-\%15 aralığı) kısmen azalırken, tüketim mallarının toplam ithalat içindeki payı (\%7-\%14 aralığı) kısmen yükselmiş ve ikisi de birbirlerine yakın düzeyde \% 12-18 aralığında pay almışlardır. (Grafik 11.)

Grafik 11.: Türkiye'de İthalatın Bileşenlerinin Cari Dengeye Etkisi (1992-2015)

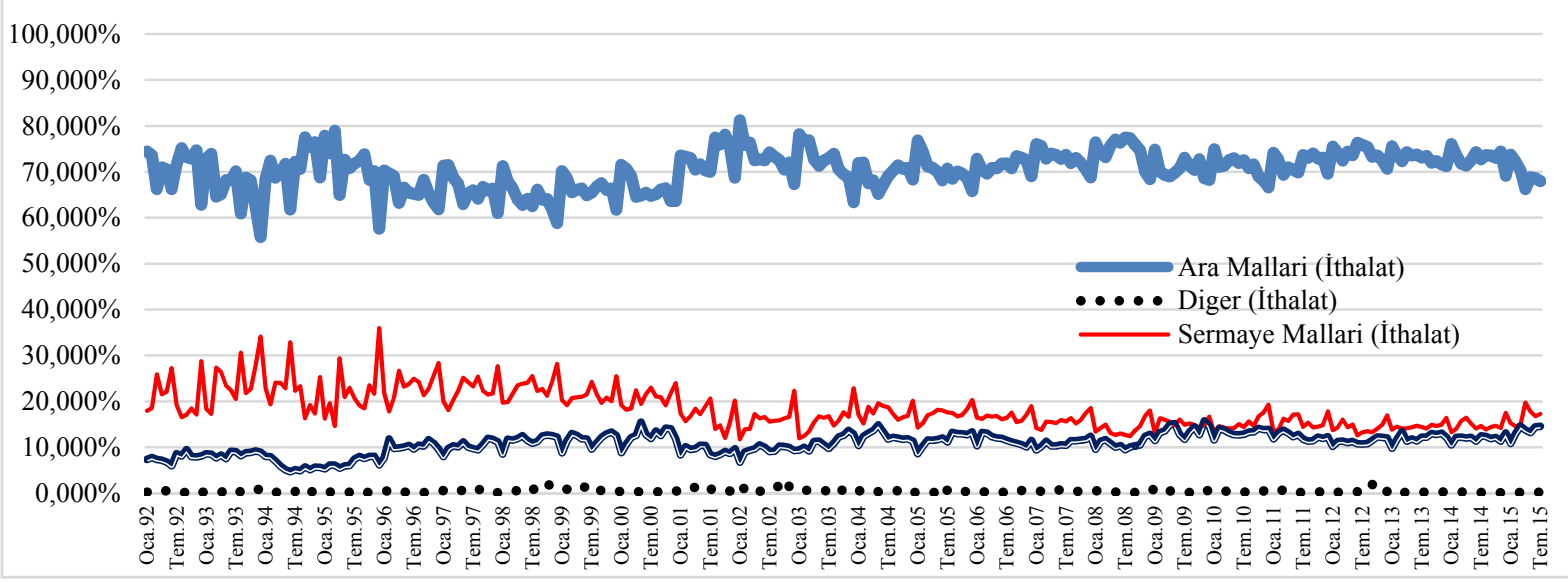

Kaynak: http://evds.tcmb.gov.tr/

\subsubsection{Reel Döviz Kuru ve Borç Dolarizasyonu}

Ulusal paranın reel olarak değer kazanması anlamına gelen reel kur artışları ithalat ve ihracat başta olmak üzere, firmalara borç dolarizasyonu altında finansal katkısıyla yatırım üzerindeki teşvik edici ve tasarruf üzerindeki caydırıcı etkisiyle cari işlemler açıklarını artırmaktadır. Bu etkilerin düzeyinde, ithal bağımlılı̆̆ı ve sektörlerin ihracat yoğunluğu gibi parametrelerin durumunu da göz ardı edemeyiz. Ayrıca dikey bütünleşme olarak tanımlanan uluslararası firmaların DYY kapsamında başka ülkelerde ürettiği bazı ürün bileşenleri sebebiyle ithal bağımlılı̆̆ı artmakta bu da reel döviz kuru esnekliklerini büyük oranda azaltmaktadır. Bunun sonucu olarak reel kur değişimleri cari açıklar üzerinde pozitif ya da negatif anlamda kayda değer bir etki bırakmaktadır. (Kalkınma Bakanlığı, 2014)

Türkiye'nin 2000'li yıllardan 2010 yılına kadar düşük kur politikası izlemesi sonucu, ulusal paranın reel değeri yükselmiş bu da yerli malları pahalılaştırarak ülke dışında rekabet gücünü kırmıştır. Diğer taraftan değerli ulusal para, yerli malları görece azaltmış ve ithalatı artırmıştır. Net ihracat makasının daralması dış ticaret açıklarını dolayısıyla cari açıkları önemli derecede etkilemiştir. 2011 sonrasında yaşanan kur değişimlerinin ihracata pozitif, ithalata negatif katkı yaptı̆̆ı gözlenmesine rağmen esneklikler yaklaşımı kapsamında beklenen düzeyin altında kalmıştır. (Grafik 12.)

Döviz kuru değişimlerinin etkileri kapsamında bahsedilmesi gereken diğer bir konu ise, firmaların borç dolarizasyonu olarak ifade edilen, toplam borçları içindeki yabancı para borçlarının oranıdır. Reel sektör firmaları 2001 krizi sonrasında büyük oranda dolarizasyon risklerinden kaçınmış olsa da, borç dolarizasyonları hala yeterli düzeyde düşmemiştir. Ulusal paranın değer kaybetmesinin, cari açıklar üzerinde gereken etkiyi gösterememesinin en temel 
nedenlerinden birisi de yüksek dolarizasyon olarak görülmektedir. Ulusal paranın reel değer kaybı ülkenin net döviz yükümlülüklerini ve dış borçların sürdürülebilirliği riskini hızla artırmaktadır. (Kalkınma Bakanlığı, 2014)

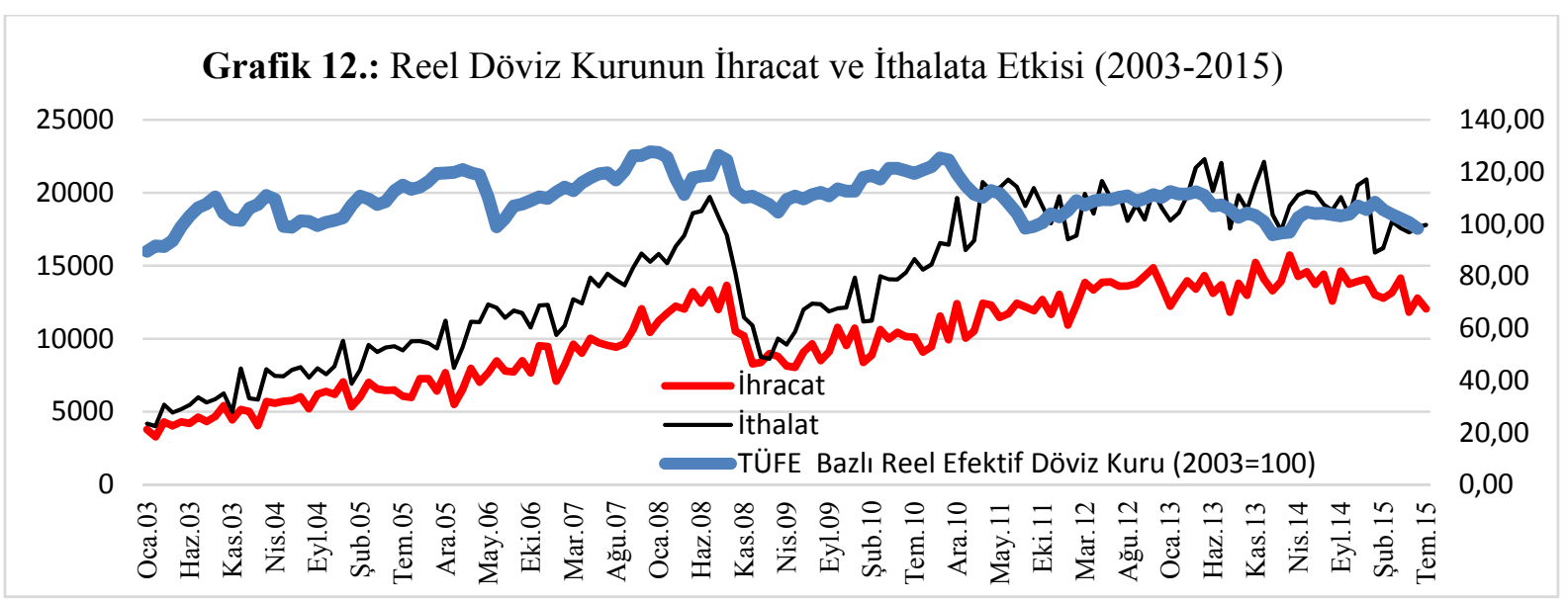

Kaynak : http://evds.tcmb.gov.tr/

\subsubsection{Gösteriş (Snop/Züppe) Tüketimi Ya Da Veblen Malları İthalatı}

Tüketim çılgınlığı ile de tanımlanabilecek tüketim davranışı, yirmibirinci yüzyıl dünya ekonomisinde öylesine ilginç boyutlara ulaşmıştır ki bazı insanlar tüketim harcamalarını adeta kendisini ifade eden bir unsur olarak görmektedirler. Hedonizm (hazcılık) kavramı ile de açıklanabilecek bu davranış kapsamında, ihtiyacı olmasa bile satın alan ve satın aldıkça mutlu olan insanların sayısı azımsanmayacak kadar çoktur. Kişiliklerinin temsil gücü olarak tüketimi gören ekonomide kibirli ya da züppe (snop) diye isimlendirilen bu kişiler, talep kanununun tersine fiyatı yükselen ürünleri talep etmekte ve kriz dönemlerinde bile bu tüketim davranışlarını içinde bulunduğu sosyal sınıfının bir gereği olarak görmektedirler. Thorstein Veblen tarafından ortaya atılan bu tüketim türü adını Veblen malları tüketimi olarak almıştır. (Dinler, 2011:54)

Bir başka yönüyle ülke ekonomilerinin dışa açılmasıyla, bireyler diğer ülkelerin ürettiği birçok yeni ve farklı ürün ile karşılaşmakta ve bu ürünlere aşırı ilgi gösterilmektedirler. Bu ilgi, giderek artan bir tüketim takibine ve modernlik göstergesine dönüşmektedir. Zenginlik göstergesi olan bu tarz lüks tüketimler, ülkenin daralma dönemlerinde bile çoğu zaman hız kesmeden devam etmektedir. Bunun en net örneği olarak küresel kriz döneminde Türkiye'nin lüks mal ithalatı kesin olmayan rakamlarla birlikte yaklaşık 2.5 milyar Euro (€) olarak gerçekleştiği öngörülmektedir. Bu rakam Türkiye'nin dünya toplam lüks tüketimde yüzde birlik bir pay edinmesine karş1lık gelmektedir. (DEİK, 03.05.2010)

Özellikle, lüks malların ithalatı ödemeler dengesini ciddi oranda etkilemekte, Türkiye gibi genellikle katma değeri düşük mal ve hizmet ihraç eden bir ülke için net ihracatı büyük oranda azaltmaktadır. Benzer şekilde, talebin iç piyasadan dışa kayması da aynı sonucu doğurmaktadır. Sürekli yaşanan ödemeler bilançosu açıkları, dış borcun artmasına neden olurken, bu borçların yatırıma dönüşmeyip tekrar tekrar tüketimi tetiklemesi, dış açıkları daha derin ve kronik bir sorun haline getirmektedir. Bu durumun doğal neticesi olarak büyüme ve istihdam sorunları kaçınılmazdır. (Öztürk,2011:459) Lüks tüketimin önlenmesi başta lüks vergi oranında yapılacak kanuni değişiklikle mümkündür. Fakat uygulamada bu tarz engelleri koymak çoğu zaman çok da kolay olmamaktadır. 


\section{Türkiye’de Cari İşlemler Açı̆̆ının Finansmanı ve Kalitesi}

Ödemeler bilançosunda, cari işlemler hesabı ve sermaye hesabı otonomdur. Yani açık ya da fazlaya sebep olan (gap-making), ekonomik hayatın normal seyri ile bağımsızca kendinden kaynaklanan hareketleri içeren hesaptır. Fakat resmi rezerv kalemine ait değişikler diğer kalemlerden kaynaklanan dengesizlik durumlarını denkleştirici (gap-filling) işlemlerdir. $\mathrm{Bu}$ açıdan cari işlemler hesabına ve sermaye hesabına çizgi üstü (above the line) kalemler denirken, resmi rezerv hesabına çizgi altı (below the line) kalemler denilmektedir. (Seyidoğlu, 2009: 317;Kaya,2008: 54) T.C. Merkez Bankasının rutin olarak açıkladığı ödemeler dengesi verileri (Ödemeler Dengesi Analitik Sunum (6.El Kitabı)) incelendiğinde cari işlemler hesabının gelirler kaleminde ihracat, hizmet gelirleri, diğer gelirler (birincil ve ikincil yatırım kaynaklı gelirler) yer alırken, gider kaleminde ithalat, hizmet giderleri ve yine diğer giderler yer almaktadır. Dış ticaret gelir gider kalemleri arasındaki farka karşılıksız transfer olarak niteleyeceğimiz cari transferlerin de eklenmesiyse cari denge verisi ortaya çıkmaktadır.

Ödemeler bilançosunun en önemli kalemi olan cari işlemler hesabında oluşan dengesizlikler (fazla ya da açık), ödemeler bilançosundaki diğer kalemler ile finanse edilmekte ya da denkleştirilmektedir. Örneğin, 2014 yılında cari işlemler hesabı, 46,531 Milyar USD açık vermiş, aynı yıl finans hesabı 42,692 Milyar USD artarken, rezevr varlıklar ise 468 Milyon USD artmış, net hata ve noksan kalemi ise 3,437 Milyar USD olarak gerçekleşmiştir. O halde cari açığın (46,531 Milyar \$) denkleştirilmesi için, finans hesabı (42,692 Milyar \$) ile rezevr varlıkların toplamından (468 Milyon \$) net hata ve noksan (3,437 Milyar \$) hesabı rakamları çıkarıldığında cari açık ile aynı rakam bulunabilmelidir. (Tablo 1.)

$$
\mathrm{CD}_{2014}=\mathrm{FH}_{2014}+\mathrm{RV}_{2014}-\mathrm{NHN}_{2014}-46531=-42692-468-3437
$$

Negatif olan veriler hesap dengesinin açık verdiğinin, pozitif olan veriler ise fazla verdiğinin ifadesi olmak üzere, Türkiye'nin 1994-2015 yılları için cari işlemler açığı ve finansman kalemleri tablo olarak verilmiştir.

Tablo 1. : Türkiye'nin Cari İşlemler Açı̆̆ı ve Finansman Kalemleri (Milyon USD) [1994-2015]

\begin{tabular}{|c|c|c|c|c|}
\hline Yıllar & $\begin{array}{c}\text { Cari Denge } \\
\text { (CD) }\end{array}$ & $\begin{array}{c}\text { Finans Hesabı } \\
(\text { FH) }\end{array}$ & $\begin{array}{c}\text { Net Hata, Noksan } \\
\text { (NHN) }\end{array}$ & $\begin{array}{c}\text { Rezerv Varlıklar } \\
(\mathrm{RV})\end{array}$ \\
\hline 1994 & 2631 & 4257 & 1832 & 206 \\
\hline 1995 & -2339 & -4565 & 2432 & 4658 \\
\hline 1996 & -2437 & -5483 & 1499 & 4545 \\
\hline 1997 & -2638 & -6969 & -987 & 3344 \\
\hline 1998 & 2000 & 840 & -713 & 447 \\
\hline 1999 & -925 & -4829 & 1302 & 5206 \\
\hline 2000 & -9920 & -9584 & -2661 & -2997 \\
\hline 2001 & 3760 & 14557 & -2127 & -12924 \\
\hline 2002 & -626 & -1172 & -758 & -212 \\
\hline 2003 & -7554 & -7162 & 4489 & 4097 \\
\hline 2004 & -14198 & -17702 & 838 & 4342 \\
\hline 2005 & -21449 & -42685 & 1964 & 23200 \\
\hline 2006 & -31837 & -42689 & -227 & 10625 \\
\hline 2007 & -37779 & -49287 & 515 & 12015 \\
\hline 2008 & -40192 & -34761 & 2733 & -2759 \\
\hline 2009 & -12010 & -9879 & 2966 & 792 \\
\hline 2010 & -45312 & -60099 & 232 & 14968 \\
\hline 2011 & -75008 & -67039 & 9008 & 1014 \\
\hline 2012 & -48535 & $\begin{array}{l}-71068 \\
\end{array}$ & 346 & 22821 \\
\hline 2013 & -64658 & -72721 & 2796 & 10763 \\
\hline 2014 & -46531 & -42692 & 3437 & -468 \\
\hline 2015Q2 & -22705 & -9540 & 8619 & -4548 \\
\hline
\end{tabular}

Kaynak: http://evds.tcmb.gov.tr/ 
Yukarıdaki tablodaki veriler grafik olarak incelendiğinde, cari açığg finanse eden kalemler daha net olarak gözlenebilmektedir.

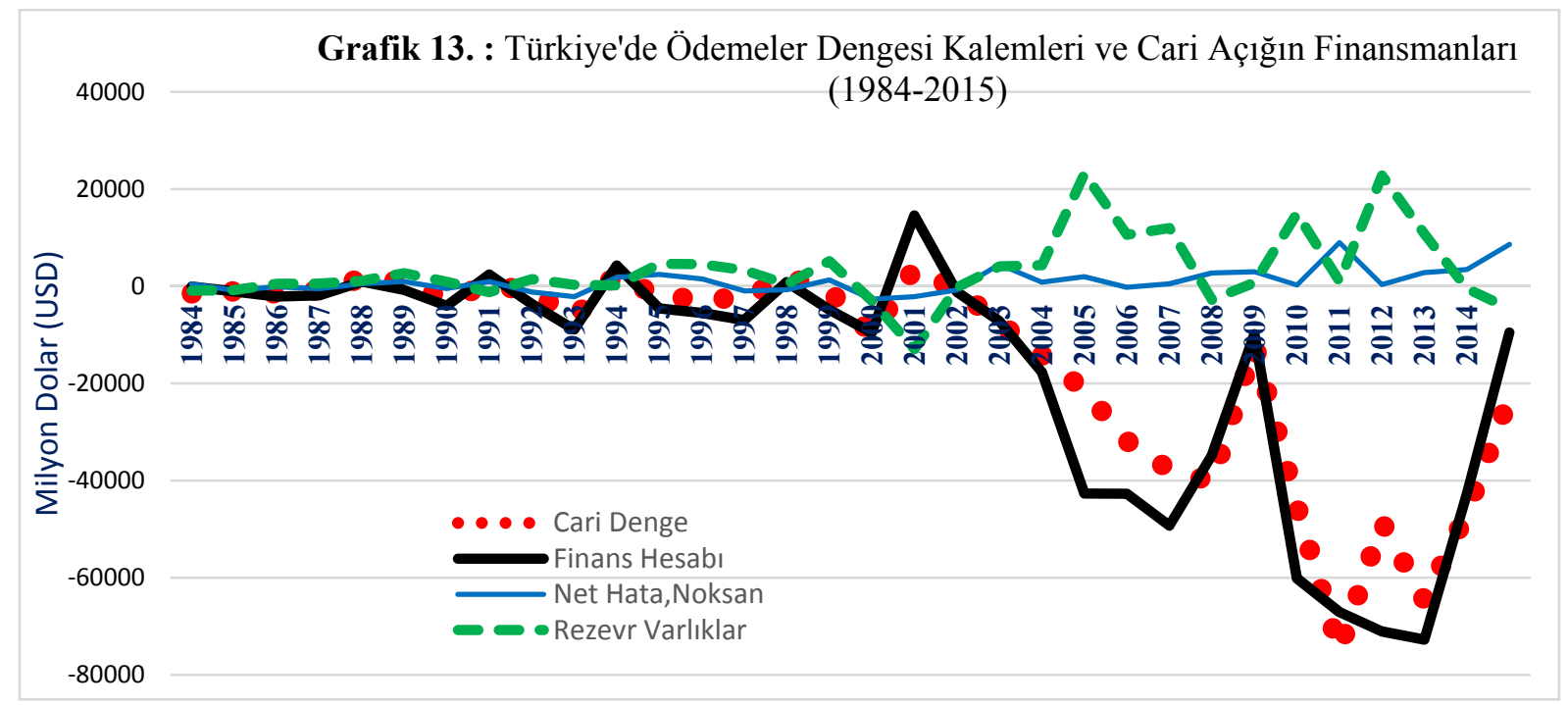

Kaynak: http://evds.tcmb.gov.tr/

Ödemeler bilançosunun finans hesabına baktığımızda, grafik hareketlerinin cari açığa oldukça benzediği görülmektedir. Zira cari açığın finansmanındaki en mühim kalem finans hesabıdır. Cari açık ile ülkeden çıkan döviz, finans hesabının alt kalemlerinden doğrudan yabancı sermaye yatırımları, portföy yatırımları (hisse senedi, borçlanma senetleri vs.) ve diğer yatırımlar (yabancılardan kredi alacakları, mevduat ve diğer alacaklar) ile finanse edilmektedir. Yani finans hesabı rakamları, cari açık yükseldikçe yükselmekte, düştükçe düşmektedir. Rezerv varlıkların değişimi incelendiğinde ise çok ciddi bir benzerlik olmamakla birlikte cari açık ile ters simetrik bir görüntü verdiği algılanmaktadır. Bu durum da resmi rezervler kaleminin denkleştirici olmasından kaynaklandığı söylenebilir. Son olarak hata terimleri olarak özetleyeceğimiz net hata ve noksan kalemi verileri 2010 yılı sonrasında daha belirgin dalgalar göstermektedir. Bu durum bize son yıllarda ülkeye ya kaynağı belirsiz para girişinin olduğunu ya da ödemeler bilançosu hesaplamalarında birçok ayrıntının gözden kaçırıldığını anlatmaktadir. (Grafik 13.)

Cari açığın makroekonomik riskleri artırıp artırmadığı ya da uzun vadede sürdürülebilir bir finansman yöntemi olup olmadığını finansman kalemlerinin kalitesi belirlemektedir. Sonuç olarak cari açıklar öyle ya da böyle bir şekilde finanse edilirler. Fakat birkaç dönemden fazlaca süren cari açıkların kronik bir sorun olduğu kabulü çerçevesinde, finansmanın kalitesinin düşüklüğü riskleri artırdığından finansal kriz olasılıklarını artırmaktadır. Dönemler arası yaklaşım çerçevesinde, verilen açıkların finansman sorunlarını uzun vadede çözecek yatırımlara dönüştürülüp dönüştürülememesi bu sorunları çözücü ya da derinleştirici etki yapmaktadır. Bu açıdan, Türkiye'de cari açıkların finansman kalitesine dönük değerlendirmeler doğrudan yabancı yatırımlar, portföy yatırımları, diğer yatırımlar, net hata ve noksan ve resmi rezervler kapsamında ele alınacaktır. 


\subsection{Doğrudan Yabancı Yatırımlar}

4875 Sayılı Doğrudan Yabancı Yatırımlar Kanunu doğrudan yabancı yatırımları (DYY) ; “1) Yurt dışından getirilen; Türkiye Cumhuriyet Merkez Bankasınca alım satımı yapılan konvertibl para şeklinde nakit sermaye, Şirket menkul klymetleri (Devlet tahvilleri hariç), Makine ve teçhizat, Sinaî ve fikrî mülkiyet hakları, 2) Yurt içinden sağlanan; Yeniden yatırımda kullanılan kâr, hâsılat, para alacă̆ı veya malî dĕgeri olan yatırımla ilgili diğer haklar, Doğal kaynakların aranması ve çıkarılmasına ilişkin haklar, Gibi iktisadî kıymetler aracılığıyla; (i) Yeni şirket kurmayı veya şube açmayı, (ii) Menkul kıymet borsaları dışında hisse edinimi veya menkul kıymet borsalarından en az \% 10 hisse oranı ya da aynı oranda oy hakkı sağlayan edinimler yoluyla mevcut bir şirkete ortak olmayl, ifade eder." şeklinde açıklamıştır.

DYY, reel ekonomiye doğrudan katkısı sebebiyle yatırımlar içinde ülkelerin (özellikle gelişmekte olan ülkeler) en çok arzu ettiği yatırım türüdür. Ekonomik kalkınma, büyüme ve istihdam başta olmak üzere birçok makroekonomik soruna yapısal çözümler getiren, kısa vadede yaşanacak muhtemel riskler karşısında ülkeyi kolayca terk etmeyen ve ekonominin arzu ettiği reel varlıkları doğrudan üreten bir yatırım türüdür. Bu nedenle, finans hesabı içerisinde DYY'lerin oranı ne kadar yüksekse dönemler arası yaklaşım planında, cari açıkların finansmanı o oranda sağlamdır ve sürdürülebilirdir. Türkiye'de DYY 2001 krizi sonrasında küresel krize kadar ciddi bir artış göstermiş; kriz sonrasında da eski seviyelerine ulaşamamıştır. Özellikle 2006-2008 yılları arasında seyreden yüksek DYY'de özelleştirme gelirlerinin etkisi yadsınamaz bir gerçektir. (Grafik 14.)

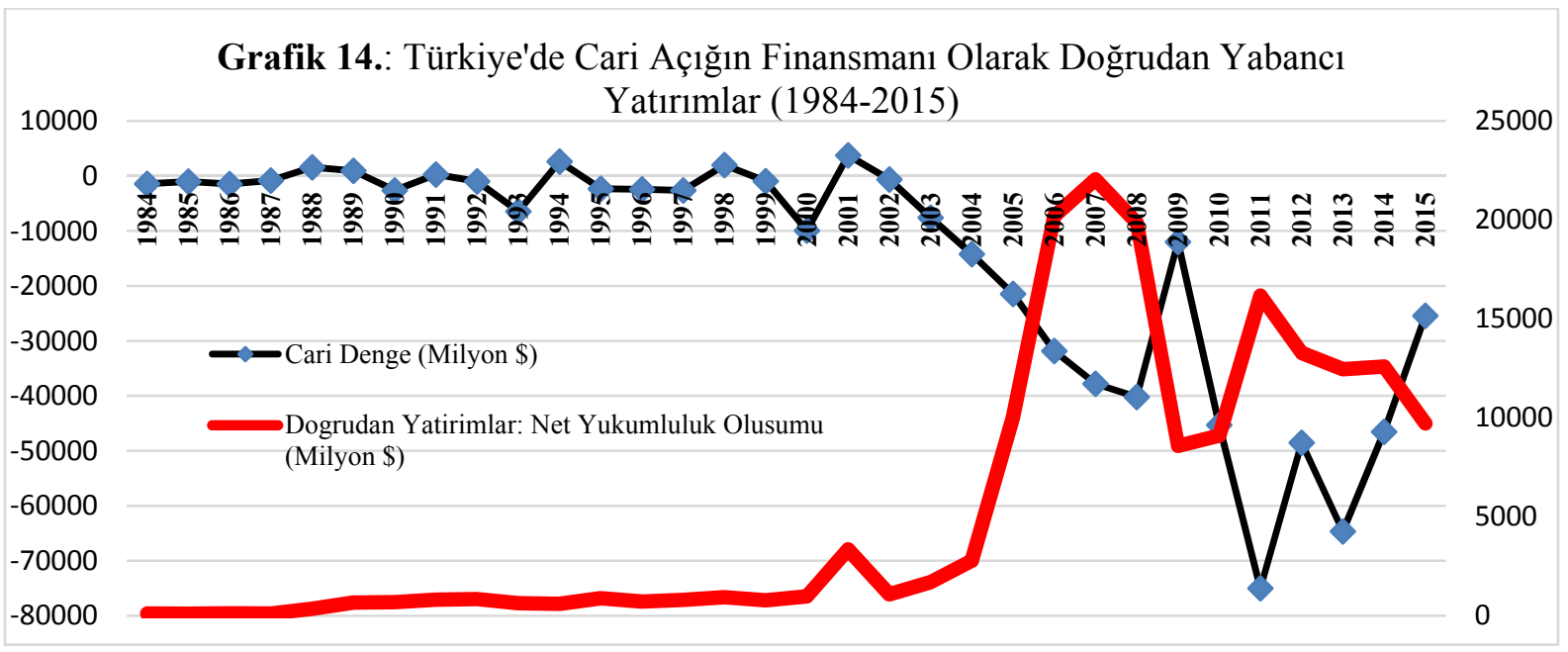

Kaynak : http://evds.tcmb.gov.tr/

\subsection{Portföy Yatırımları}

İster yerleşiklerden dış dünyaya, ister dış dünyadan bahse konu ülkeye yapılsın yabancı yatırımlar farklı şekillerde gerçekleşse de, genel olarak doğrudan yatırımlar ve portföy yatırımları olarak iki kategoride değerlendirilebilir. Doğrudan yatırımlarda yatırımcı, yatırım yaptığ1 şirket yönetiminde etkin iken portföy yatırımlarında böyle bir durum söz konusu değildir. Sıcak para olarak ifade edilen portföy yatırımında yatırımcı yatırım yaptığı şirkete sadece finansal kaynak sağlamıştır. Doğrudan yatırımcı sadece sermayesini değil beraberinde potansiyel olarak sahip olduğu üretim teknolojisi ve işletmecilik tecrübesini de getirmektedir. Portföy yatırımları kısa vadeli (hazine bonosu, finansman bonosu, mevduat sertifikası vs.) ve uzun vadeli (tahvil, hisse senedi vs.) finansal araçların alım satımının yapıldığı para ve sermaye piyasası araçlarını içeren bir yatırım türüdür. Yurtiçi yerleşiklerin yurtdışından edindikleri menkul kıymetler, varlıklar kalemine kaydedilirken, yurtdışı yerleşiklerin yurtiçinden aldıkları 
menkul kıymetler yükümlülükler kalemine kaydedilmektedir. Portföy yatırımları kalemi altında başka bir sınıflandırma olarak, Merkez Bankası, hükümet, özel sektör gibi borçlanan kurum ayrımı da yapılabilmektedir.

Portföy yatırımları, niteliği gereği riskin az olduğu ve getirinin yüksek olduğu yöne doğru hareket etmektedir. Risk unsurlarında (siyasi, ekonomik, hukuki, konjonktürel vs.) meydana gelebilecek her olay ya da olguda portföy yatırımcısı doğrudan yatırımcıya nispeten daha net ve hızlı tepkiler vermektedir. Portföy yatırımcısı finansal kriz ya da temerrüt olasılığının yüksek olduğunu öngörürse hızlı bir şekilde yatırım yaptığı ülkeyi terk edebilir. Bu açıdan portföy yatırımlarının tüm yatırımlar içindeki payının artması cari açıkların finansmanı konusunda riskleri artırmaktadır. Finansman kalitesi perspektifinde bir diğer konu ise, portföy yatırımlarının vade sorunudur. Kısa vadeli yatırımlar uzun vadeli yatırımlara göre yatırım alan ülke için daha çok risklidir. Bu anlamda para değil de sermaye piyasasının derinleşmesi finansman kalitesini artıracaktır.

Türkiye'de portföy yatırımlarının gelişimi incelendiğinde, 2000 yılı öncesindeki ekonomik ve siyasi istikrarsılıkların etkisi büyük dalgalanmalar (volatilite) çerçevesinde net olarak görülmektedir. 2000 ile 2008 yılları arasında ise portföy yatırımları ilk yıllarda hızlı artarken küresel krize kadar bazı dalgalanmalar göstermekle birlikte tekrar azalmaya başlamıştır. Küresel kriz sonrasında gelişmekte olan birçok ülke gibi Türkiye'de de bollaşan likidite sayesinde portföy yatırımları 2012'de rekor kırmış ve 2014 yılına kadar yüksek sayılabilecek bir performans göstermiştir. Bu tarihten sonra ise Türkiye'nin içinde bulunduğu bazı politik ve ekonomik sorunlar ve FED'in yakın bir tarihte (2016 öncesinde) daraltıcı politika yapacağı beklentisi nedeniyle portföy yatırımları tekrar bir düşüş trendine girmiştir. (Grafik 15.)

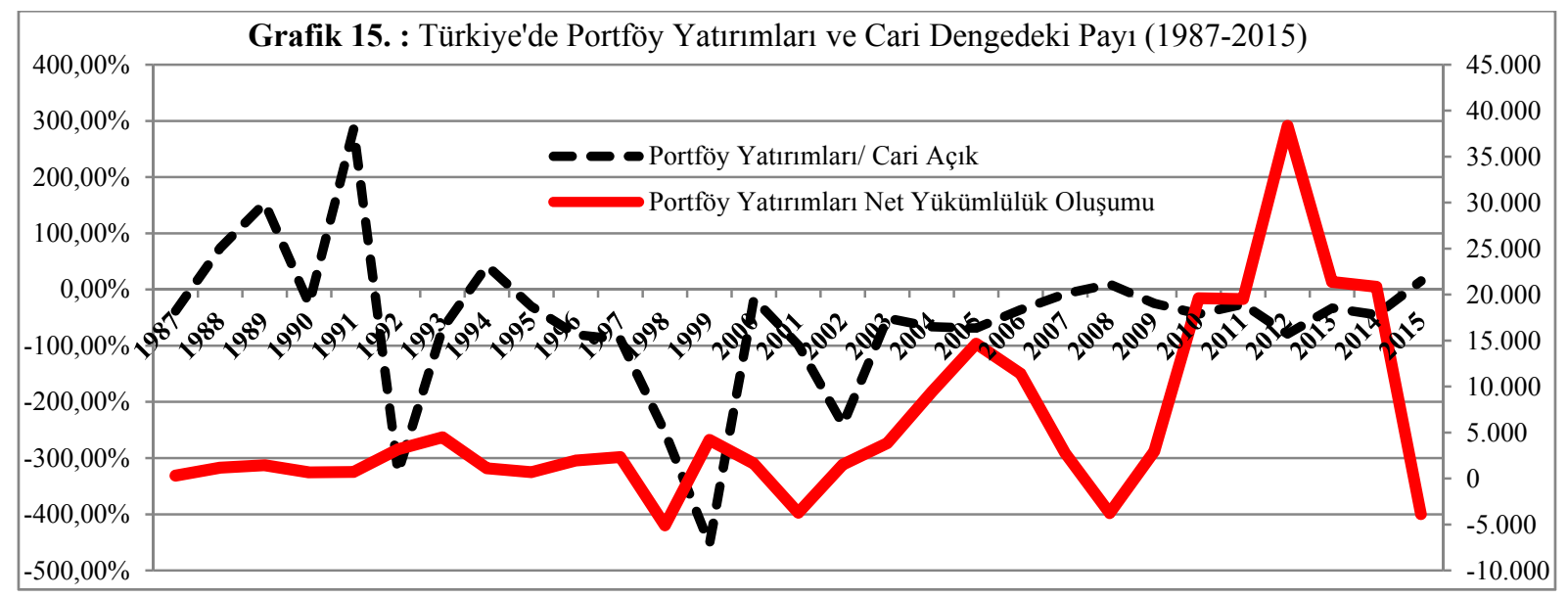

Kaynak: http://evds.tcmb.gov.tr/

Türkiye'deki cari açıkların ne kadarının portföy yatırımları ile finanse edildiğinin bilinmesi amacıyla portföy yatırımlarının cari açıklara oranına bakabiliriz. Bu oran 2003-2008 y1lları arasında ortalama \%35 düzeylerinde iken, 2009-2014 arasında \%42'lere yükselmiştir. $\mathrm{Bu}$ yükselişi bir de kısa vadeli portföy yatırımları çerçevesinden değerlendirir isek, cari açıkların sürdürülebilirliği anlamında risklerin arttığı söylenebilir.

\subsection{Net Hata ve Noksan}

Ödemeler dengesine kaydedilen verilerin farklı kaynaklardan temin edilmesi, dış ticaret işlemlerinde miktar ve değerlerin sehven ya da yanlış yazılması, kaçakçılık, turizm, karşılıksız transferler, bazı rakamların tahmini yazılması ve dış ticaret işlemlerinde sarkan ödemeler gibi 
nedenlerle değerleme ve ölçme hatası oluşmaktadır. $\mathrm{Bu}$ açıdan ödemeler bilançosunun muhasebe anlamında denk olması için bir denkleştirici bir kaleme ihtiyaç vardır. "İstatistiki farklar" ya da "net hatalar ve unutmalar hesabı" kavramlarına da denk olan net hata ve noksan kaleminde açıklanan rakamlar ne kadar küçükse, genel anlamda (istisnai durumlar hariç) ödemeler bilançosu verileri o kadar gerçeğe yakındır diyebiliriz. Aksi durumda kaynağı belirlenemeyen ödemeler söz konusudur. (Seyidoğlu,2009:327; Yalçıner,2012:144; Krugman vd.,2011:342)

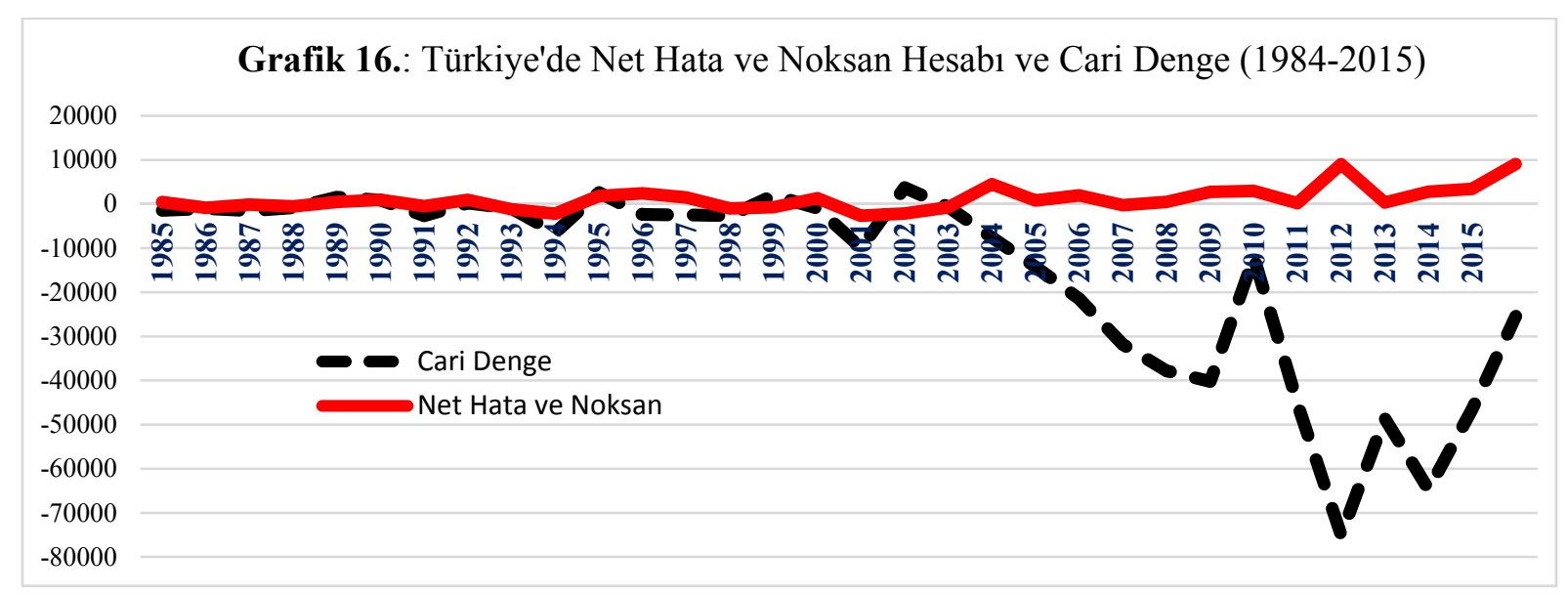

Kaynak: http://evds.tcmb.gov.tr/

$\mathrm{Bu}$ kalemde ortaya çıkan rakamlar mutlak değerce aşırı büyük olmadığı takdirde ödemeler bilançosunda hiçbir önemi yoktur. Cari dengesizliklerin finansman kalitesi anlamında da değerlendirilebilecek bir özelliği de yoktur. Sadece muhasebel bir denkleştiricidir. Şayet net hata ve noksan kalemi sürekli olarak kayda değer düzeyde açık ya da fazla veriyorsa, yapısal, hukuki ya da istatistiki anlamda bazı sorunlara işaret etmektedir. Türkiye'de cari açık sorunlarının hızla arttığı 2002 sonrası incelendiğinde, bu kalemde kısmi dengesizlikler görülmekle birlikte, 2011 sonrasında ciddi sayılabilecek hareketler göze çarpmaktadır. Türkiye'de özellikle son yıllarda kaynağı belirsiz bir para girişi gözlenmektedir. Türkiye'de 2014 yılında 3,43 milyar USD değerinde kaynağı belirsiz para girişi olmuşken, 2015 yılının Ağustos ayı itibariyle bu rakam 10,9 milyar USD düzeyindedir. (evds.tcmb.gov.tr) Bu rakam sekiz aylık bir toplam olmasına rağmen yıllık toplam olarak bile Cumhuriyet tarihinde kırılamamış bir rekordur. Bir diğer açıdan ise, 10,9 milyar USD değerinde net hata ve noksan kaleminin cari açıkların yaklaşı \% 45 'ne karşılık geldiği söylenebilir. Finans hesabında azalan varlıkların yerini alan bu durum, örneğine pek rastlanmayan ve yorumu karmaşık bir durumdur. Cari açık finansmanı olarak kaliteli ve sürdürülebilir bir kaynak olmadığı çok nettir.

\subsection{Resmi Rezervler}

Keynes'in para talebi teorisindeki ihtiyat güdülü para talebine benzer bir mantıkla, para otoritesinin kasasında bulundurduğu altın, SDR ve döviz cinsi paraların genel adı resmi rezervlerdir. Kendisi otonom olmayıp, otonom olan diğer kalemlerdeki açık ya da fazlaları denkleştirici olma özelliği nedeniyle çizgi altı kalemlerden sayılan resmi rezerv hesabı, özü itibariyle merkez bankasının piyasaya müdahalesi sonucu TCMB kasasındaki rezerv değişimlerini içermektedir. Cari işlemler ve sermaye hesaplarının verdiği açık kadar resmi rezerv hesabı borçlu bakiye vermektedir. Açık ya da fazlalar nedeniyle ulusal piyasada bollaşan ya da kıtlaşan döviz nedeniyle, yükselen ya da düşen kura müdahale rezervler aracılığı ile yapılmaktadır. 
Optimum rezerv oranı için, öne çıkan en temel finansal göstergeler olarak, rezervlerin ithal edilen mal ve hizmetler toplamına oranı ve rezervlerin kısa vadeli dış borç stokuna oranı dikkate alınmaktadır. IMF'nin bu konudaki önerisi ise rezerv oranının en az üç aylık ithalat tutarında denk olması gerektiğidir. (Yalçıner,2012:141) "Döviz rezervleri/kısa vadeli dış borçlar" oranının maksimum olması gerekir. Yani bir yılda rezervlerin vadesi yakın döviz türünden diş ve iç borç ödemelerini finanse etmeye yetecek düzeyde olması gerekmektedir. (TCMB,2005)

Türkiye'de 2001 yılı sonrasına bakıldığında 2005, 2010, 2012 ve 2013 gibi yıllarda cari açıkların finansmanında rezerv varlıkların büyük oranda kullanıldığı göze çarpmaktadır. Cari açıkların yükselmesinin net sonucu olarak finansmanında resmi rezervlerin kullanımı genel olarak artmaktadır. 2001 yılı sonrasında 2013 yılına kadar ciddi bir artış trendinde olan TCMB rezervlerinin son iki yılda bir miktar eridiği görülmektedir. Şayet cari açıklar diğer finansman kaynakları ile finanse edilemez ve sürekli olarak resmi rezervler ile finanse edilirse, bu rezervler çok kısa sürede eriyecektir. Her ne kadar TCMB resmi rezervlerinin büyüklüğ̈ tatminkar düzeyde olsa da, Türkiye'de son zamanlarda düşen net ihracat, azalan DYY ve uzun vadeli portföy yatırımları perspektifinde yüksek düzeydeki cari açıkların finansmanında bir takım sorunlara yol açacak gibi görünmektedir. (Grafik 17.)

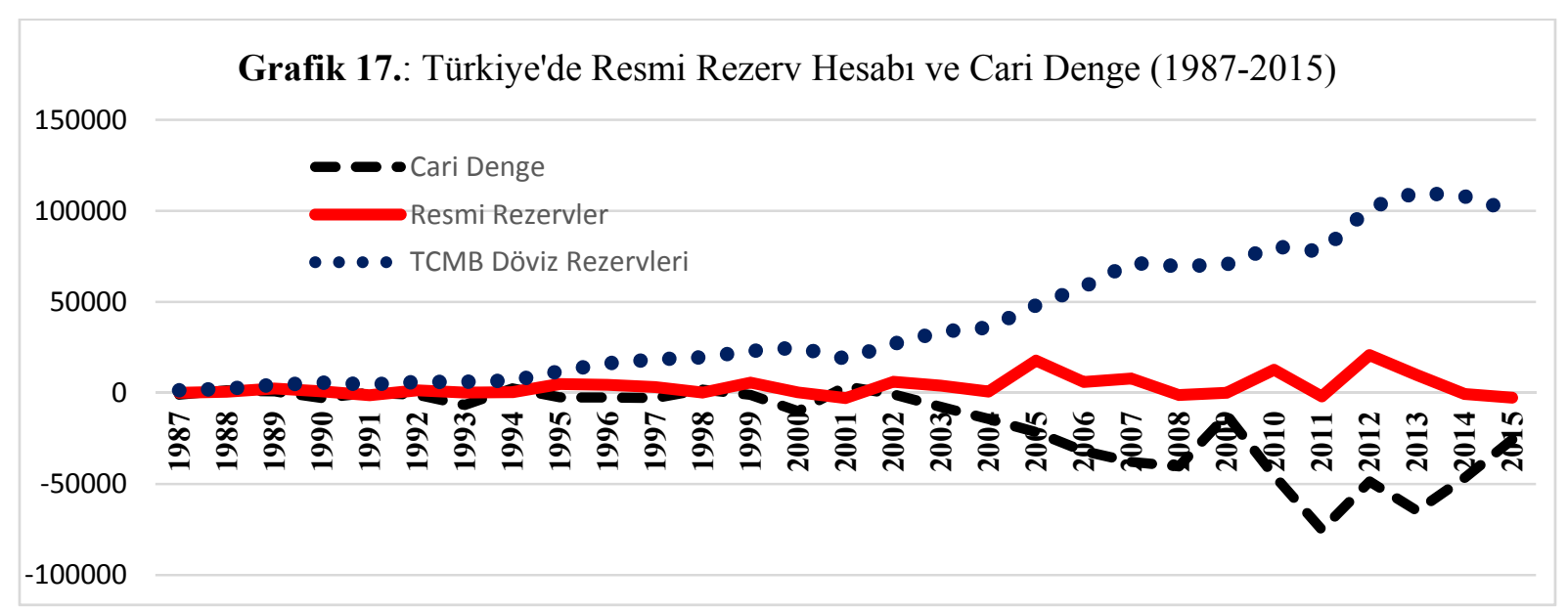

Kaynak: http://evds.tcmb.gov.tr/

\section{Cari Denge Perspektifinde Türkiye'nin Uluslararası Konumu}

Cari dengesizliklerin (açık ya da fazla) tek başına yorumlanması bir ekonomi için yeterli değildir. İllaki cari açıklar yorumlanacak ya da başka ekonomiler ile karşılaştırılacak ise bunun en doğru yöntemi Cari Açık / GYSH oranına bakmaktır. Bu oran ekonominin büyüklüğü nispetinde dengesizliklerin değerlendirilmesine imkân tanımaktadır. Bir ekonominin bir ya da birkaç dönemde cari açık vermesi de, tek başına büyük bir sorun teşkil etmeyebilir. Şayet Türkiye gibi, en az 12 yıldır cari açık veren bir ekonomiden bahsediyor isek, burada bir takım yapısal sorunlar mevcuttur diyebiliriz. Cari Açık / GSYH oranının sürdürülebilirlik anlamında üst sınırının ne olacağı ile ilgili kesin bir teorik bilgi olmamakla birlikte $\% 4$ ya da $\% 5$ seviyesi önemli bir eşik olarak kabul edilmektedir. Türkiye kimi zaman bu değerin etrafinda dalgalansa da son yıllarda bu değerin çoğunlukla üzerinde seyretmektedir.

2013 yılında gerçekleşen veriler kapsamından 185 ülkenin cari açı̆̆ının GSYH'ya oranı baz alınarak en küçükten (en kötüden) en büyüğüne (en iyiye) doğru bir sıralama yapılmıştır. Bu oranın (Cari Açık / GSYH) Türkiye için \% -7.86352 olduğu 2013 yılında, Türkiye 51 ülkeden daha iyi 133 ülkeden ise daha kötü bir performans göstermiştir. (Tablo 2.) Yine aynı bakış açısı ile Türkiye, 2012'den 2000 yılına kadar sırasıyla 71. , 52. , 72. , 109. , 96. , 84. , 
65. , 81. , 82. , 88. , 116. , 137. ve 77. en kötü sırada yer almıştır. 2000-2013 yıllarının esas alındığı son 13 yılın ortalamasına göre, Türkiye Cari Açık / GSYH oranında 195 ülke arasından en kötü 92. ülke olurken, 1980-2013 yılları arasındaki ortalamaya bakıldığında ise 202 ülke arasından en kötü 123. ülke olmuştur. (Grafik 18.)

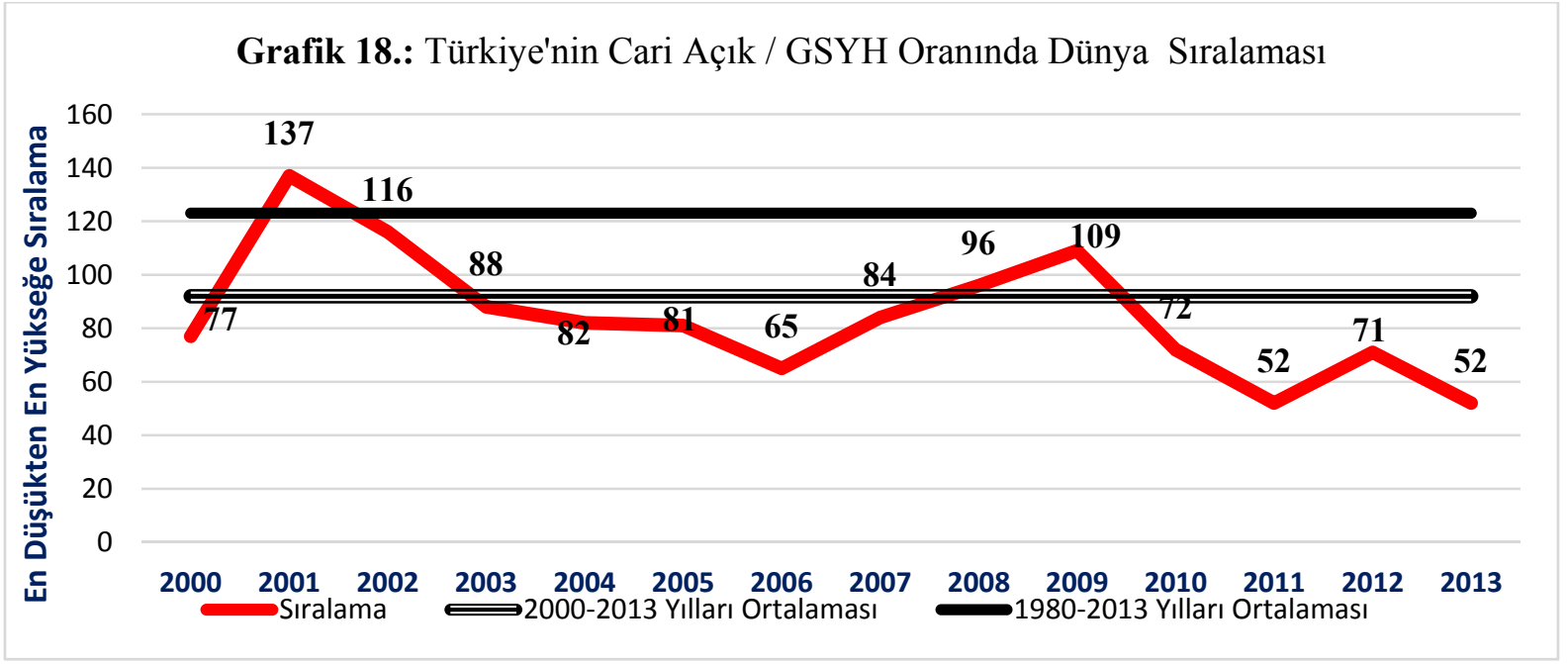

Kaynak : http://unctadstat.unctad.org

Türkiye'nin \% -4.47 Cari Açık/GSYH oranına sahip olduğu ve en kötü 92. sırada yer aldığı son 13 yılın ortalamasına baktığımızda, İspanya \% -5.03 ile 86. , İngiltere \% -2.45 ile 112., İtalya \%-1,54 ile 121., Brezilya \%-1.05 ile 126., Fransa \% -0.54 ile 131., Japonya \%2,91 ile 157. sirada yer almaktadir. 
Tablo 2.: 2013 Yılına Ait Cari Açık / GSYH Oranı Ülke Sıralaması

\begin{tabular}{|c|c|c|c|c|c|}
\hline SIRA & Ülkeler & Cari Açık / GSYH & SIRA & Ülkeler & Cari Açık / GSYH \\
\hline 1 & Montserrat & -41.3884 & 107 & Belçika & -1.90699 \\
\hline 2 & Mozambik & -37.9221 & 108 & Ekvador & -1.88812 \\
\hline 3 & Saint Vincent ve the Gren. & -29.2004 & 109 & Tacikistan & -1.86826 \\
\hline 4 & Papua Yeni Gine & -28.9061 & 110 & Pakistan & -1.85018 \\
\hline 5 & Moğolistan & -27.182 & 111 & Fransa & -1.46783 \\
\hline$\ldots$ & ... & $\ldots$ & 112 & Çek Cumhuriyeti & -1.43893 \\
\hline 49 & Kenya & -8.30776 & $\ldots$ & $\ldots$ & ... \\
\hline 50 & Benin & -8.22451 & 117 & Surbistan & -1.06292 \\
\hline 51 & Sudan & -8.16571 & 118 & Finlandiya & -0.95946 \\
\hline 52 & Türkiye & -7.86352 & 119 & Arjantin & -0.89441 \\
\hline$\ldots$ & $\ldots$ & $\ldots$ & 120 & Letonya & -0.80646 \\
\hline 78 & İngiltere & -4.50812 & 121 & Tayland & -0.65538 \\
\hline 79 & Myanmar & -4.5062 & 122 & Botsvana & -0.36348 \\
\hline 80 & Kamerun & -4.28132 & 123 & Kazakistan & -0.05342 \\
\hline 81 & Fil Dişi Sahilleri & -4.20392 & 124 & Cezayir & 0.437942 \\
\hline 82 & Burkina Faso & -4.17326 & 125 & Portekiz & 0.527728 \\
\hline 83 & Dominik Cumhuriyeti & -4.1092 & 126 & Japonya & 0.690715 \\
\hline 84 & Solomon Adaları & -4.10824 & 127 & Yunanistan & 0.729916 \\
\hline 85 & Sri Lanka & -4.04047 & 128 & İspanya & 0.786296 \\
\hline 87 & Yemen & -3.73102 & 129 & Malta & 0.911002 \\
\hline 88 & Brezilya & -3.60272 & 130 & İtalya & 1.027428 \\
\hline 89 & Türkmenistan & -3.57017 & 131 & Zambiya & 1.129221 \\
\hline 90 & Șili & -3.39943 & 132 & Hirvatistan & 1.235822 \\
\hline 91 & Yeni Zellanda & -3.3704 & 133 & Litvanya & 1.469449 \\
\hline 92 & Kolombiya & -3.34008 & 134 & Russian Federasyonu & 1.527932 \\
\hline 93 & Endonezya & -3.27391 & 135 & Bangladeș & 1.554824 \\
\hline 94 & Kanada & -3.24114 & $\ldots$ & $\ldots$ & $\ldots$ \\
\hline 95 & Eritre & -3.10824 & 140 & Çin & 1.96168 \\
\hline 96 & Avustralya & -2.89709 & $\ldots$ & $\ldots$ & $\ldots$ \\
\hline 97 & Guatemala & -2.68625 & 176 & Birleşik Arap Emirliği & 15.06152 \\
\hline 98 & Hindistan & -2.55792 & 177 & Azerbaycan & 17.07306 \\
\hline$\ldots$ & $\ldots$ & $\ldots$ & 178 & Trinidad \& Tobago & 18.10515 \\
\hline 102 & Misır & -2.24809 & 179 & Suudi Arabistan & 18.5687 \\
\hline 103 & $\mathrm{ABD}$ & -2.24277 & 180 & Singapur & 19.16348 \\
\hline 104 & Meksika & -2.04935 & 181 & Katar & 31.29161 \\
\hline 105 & Kibris & -1.9433 & 182 & Tuvalu & 37.26958 \\
\hline 106 & Makedonya & -1.91734 & 183 & Kuveyt & 37.53633 \\
\hline \multicolumn{6}{|c|}{ Kaynak : http://unctadstat.unctad.org } \\
\hline
\end{tabular}

En sade haliyle cari dengeyi, ihracat başta olmak üzere döviz kazandıran cari işlemler ile ithalat başta olmak üzere döviz kaybettiren cari işlemlerin birbirine denkliği olarak ifade edebiliriz. Durumu görselleştirmek maksadıyla, bu iki değişkeni koordinat düzleminde eksenlere yerleştirir isek, birinci açırtay doğrusu adı verilen doğru cari dengeyi ifade etmektedir. (Mahfi Eğilmez, 29.09.2013) Bu dengenin üst kısmında kalan bölgeyi cari fazla bölgesi, alt kısmında kalan bölgeyi ise cari açık bölgesi olarak belirleyebiliriz. Bu bölgelerdeki noktalar orijinden uzaklaştıkça ekonominin büyüdüğü de söylenebilir. Türkiye'nin 1992 yılı ocak ayından 2015 yılının temmuz ayına kadar aylık cari gelir - gider ikilileri oluşturulduğunda, bu ikililerin çok büyük bir kısmının cari açık bölgesinde kaldığı görülmektedir. (Grafik 19.) 


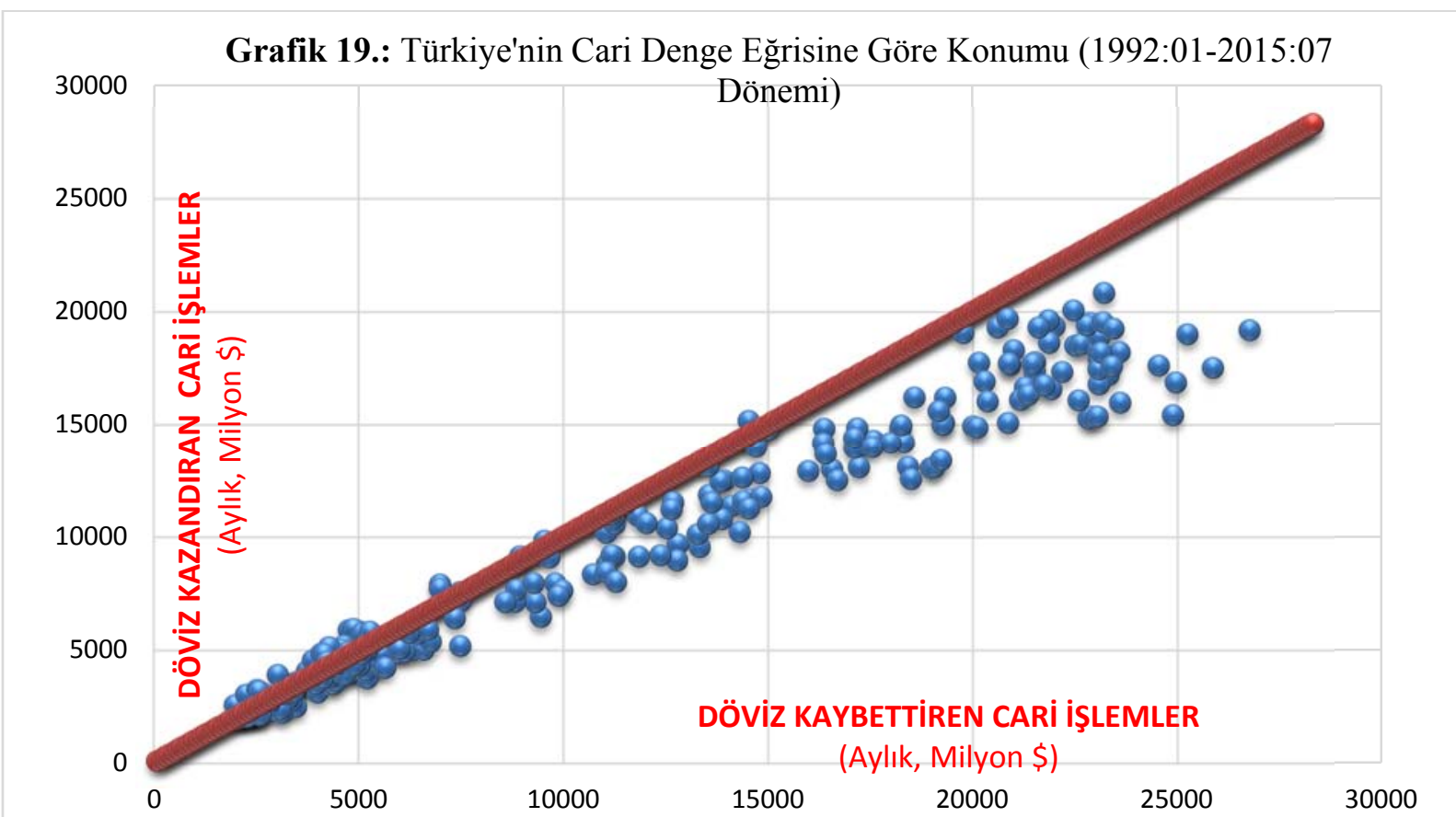

Kaynak : Mahfi Eğilmez'den (29.09.2013) esinlenerek http://evds.tcmb.gov.tr/ verileri ile yazar tarafindan tasarlanmıştır.

Ülkenin ürettiği GSYH'nın büyüklüğü nispetinde farklı bütün noktalar grafikte gösterilen doğru üzerinde cari dengeye sahiptir. Yani bahsi geçen doğru üzerindeki noktaları temsil eden ülkeler kazandığı kadar dövizi harcayarak cari işlemlerini dengede tutmaktadır. Bu doğrunun üst kısmında yer alan bütün ülkelerde döviz kazancı döviz kaybından daha büyük olduğundan cari fazla bulunmakta, aksi durumda ise doğrunun altında kalan ülkeler cari açık vermektedir. Ülkeleri temsil eden noktaların aşağıda ya da yukarıda olması, ülkenin GSYH'nın ve cari açığın (fazlanın) büyüklüğü ile ilgilidir.

205 ülkenin 1980-2013 yıllarını kapsayan 34 yıllık cari işlemler hesabına ait verilerinin ortalaması alınmış ve Grafik’te bu ülkelerin bir kısmı resmedilmiştir. En yüksek cari açıktan en yüksek cari fazlaya kadar bir sıralama yapıldığında, ilk beş sırada ABD, İngiltere, İspanya, Brezilya ve Türkiye yer almakta iken, son beş sırada Japonya, Almanya, Çin, Rusya ve Suudi Arabistan yer almaktadır. Cari dengeye en yakın üç ülke olarak, Afrika ülkesi Gambiya ile birlikte küçük ada ülkeleri Montserrat ve Tuvalu gibi ülkeler bulunmaktadır. 
Grafik 20.: Türkiye'nin 2013 Y1lı Cari Denge/GSYH’ya Göre Uluslararası Konumu

\section{DÖVIZ KAZANDIRAN CARI IŞLEMLER (Milyon \$)}

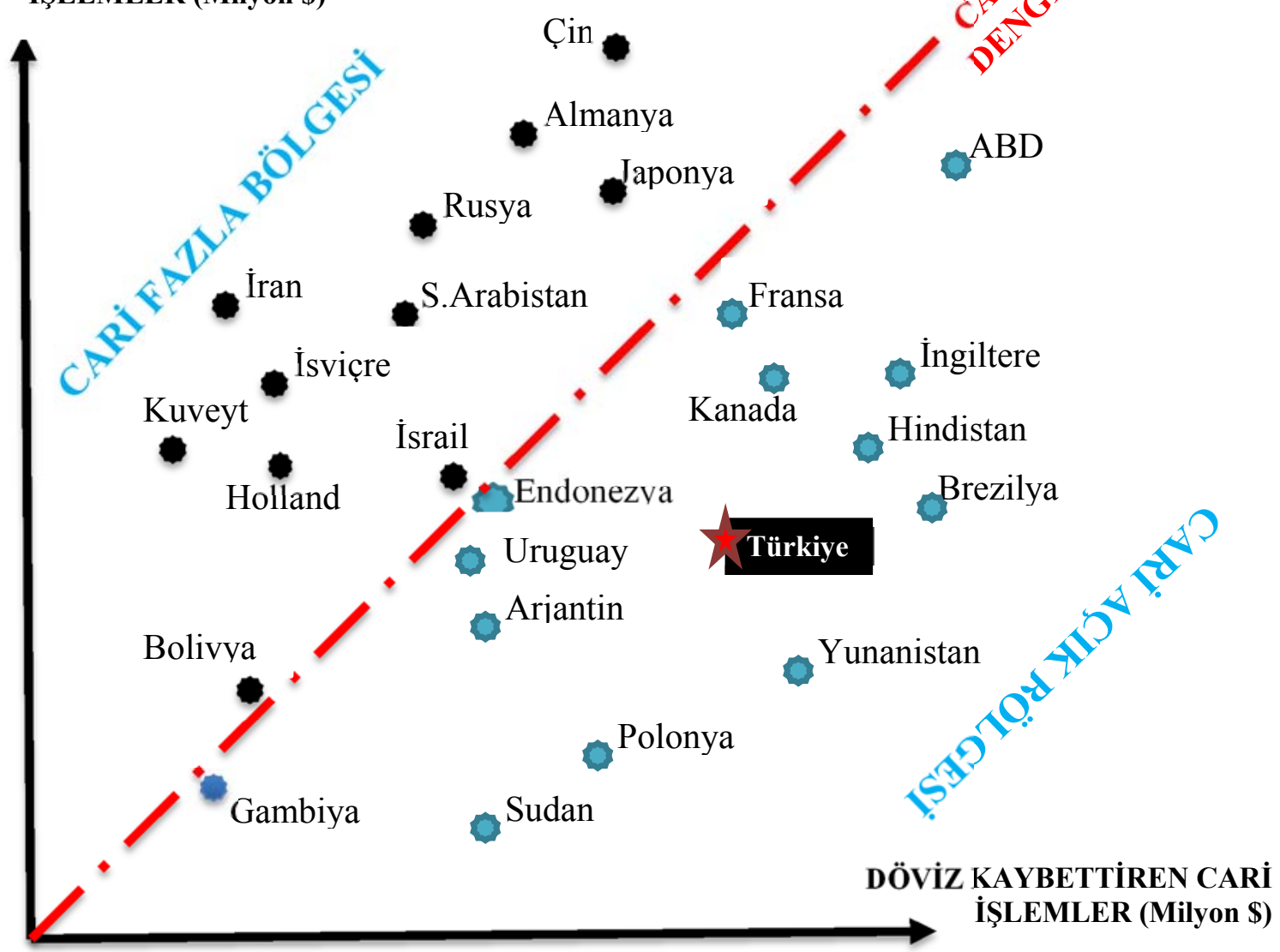

Kaynak : Mahfi Eğilmez, (29.09.2013, Kendime Yazılar) esinlenerek, http://unctadstat.unctad.org/ 'dan temin edilen veriler kullanılarak yazar tarafından tasarlanmıştır.

\section{Sonuç}

Ekonomilerin her dönemde mücadele etmesi gereken bir takım makroekonomik sorunlarının bulunması alışılagelmiş bir durumdur. Önemli olan bu sorunların yapısal nedenlerini doğru belirleyip tedavi edici politikalar yürütebilmektir. Fakat makroekonomik değişkenler genellikle içsellik sorunu içermektedir. Yani değişkenler birbirlerini doğrudan ya da dolaylı olarak etkilemektedirler. Bu kapsamda makroekonomik bir sorunu çözmek üzere uygulanan bir politika başka bir değişken üzerinde bozucu etkiler oluşturabilmektedir. Türkiye'nin uzun süredir yaşadığı cari açık sorununun temelinde de bu kavram yatmaktadır. 2002 öncesinde potansiyelin altında büyüyen ülke ekonomisi 2003'den itibaren iyi bir trend yakalamıştır. Fakat yukarıda bahsedilen bilgi ışığında, artan büyüme oranları ile birlikte cari dengenin yapısı da ciddi derecede bozulmuştur. Tek sebep olarak bu konu bahsedilemese de diğer nedenleri de çoğunlukla kapsayan yüksek büyüme hedefleri cari açıklar üzerindeki en büyük baskıdır. Bunun dışında Türkiye'de cari işlemler açığının sebeplerini, dış ticaret açıkları, hammadde ve enerjide dışa bağımlılık, yurtiçi yatırım tasarruf açığı, bankacılık sektörü kredi genişlemesi, DYY ve portföy yatırımların kar transferleri, reel döviz kuru ve borç dolarizasyonu ve lüks mal ithalatı şeklinde özetleyebiliriz. 
Cari açıkların nedeni kadar, belki de daha önemli bir konu varsa şüphesiz bu cari açığın nasıl finanse edildiği ve finansman kalemlerinin kalitesidir. Cari açıkların finansman kaynaklarını temel olarak DYY, portföy yatırımları, resmi rezerv hesapları ve net hata ve noksan kalemleri olarak siralayabiliriz. Bu kalemlerin finansman kalitesi olarak bir siralamasi yapılırsa bu sıralama yukarıdaki gibi olmalıdır. Finansmanın kaliteli olmasının anlamı, dönemler arası bütçe kısıtı çerçevesinde reel ekonominin kapasitesini artırması, nispeten uzun vadeli olması, geçici değil kalıcı ve güvenilir olması, küçük risk dalgalanmaları karşısında ülkeyi hemen terk etmemesi ve cari dengenin kırılganlığını azaltması demektir.

Türkiye'de cari açıkların finansman kalitesini ise şöyle özetleyebiliriz. Son yıllarda özelleştirilmelerin azalmasının ve artan riskin etkisiyle doğrudan yabancı yatırımlarda düşüşler yaşanmıştır. Portföy yatırımlarında 2012 öncesinde uzun vadeli borçlanma araçlarının yüksek olan payını kısa vadeli borçlanma araçları devralmıştır. Özellikle son aylarda TCMB'nin rezerv varlıklarında bir miktar erime yaşanmıştır. Son olarak tek başına hiçbir şey ifade etmese de, net hata ve noksan kaleminde gerçekleşen çok yüksek hacimli rakamlar 2015 yılının 3. çeyreğinde 11 milyarı (USD) aşmıştır. Özet olarak ifade edilen bu gelişmelerin hepsi, cari açığın finansman kalitesini düşürmekte ve ülkenin dışa bağımlılığı çerçevesinde kırılganlığını artırmaktadır. Kesin ve net bir dille cari açıklar sürdürülebilir ya da sürdürülemez ifadesini kullanmak yerine "Türkiye'de cari açıklar eskiye nazaran daha kırılgandır." demek daha doğrudur.

\section{REFERENCES}

- AA (30.11.2013) "En az tasarruf oranı Türkiye'de" http://www.aa.com.tr/tr/ekonomi/en-az-tasarruf-orani-turkiyede/200897, Erişim Tarihi: :06.10.2015

- DEİK (03 Mayıs 2010) "Türkiye Krizde Lükse 2.5 Milyar Euro Harcadı." Dış Ekonomik İlişkiler Kurumu, Güncel, Sayfa 7

- Dinler, Z. (2011) “İktisada Giriş” Ekin Yayınevi, 16.Basım, Bursa

- IMF, Uluslararas1 Para Fonu, http://www.imf.org/,

- Kalkınma Bakanlığı (2014) “Türkiye'de Cari İşlemler Açığı” 10.Kalkınma Planı 20142018, Özel İhtisas Komisyonu Raporu, Ankara (Yayın No: KB: 2907 - ÖİK: 746)

- Kaya, S. (2008) "İthalat, İhracat ve Kambiyo İşlemleri”, Beta Basım Yayıncılık, İstanbul

- Kaymakçı, O., Avcı, N. Ve Şen, R. (2007) "Uluslararası Ticarete Giriş : Teori, Politika ve Uygulama" Nobel Yayın Dağıtım, Ankara

- Kendime Yazılar, http://www.mahfiegilmez.com/

- Krugman, P.R., Obstfeld, M. \& Melitz, M.J. (2011) "International Economics : Theory \&Policy", 9th (Global) Edition, The Pearson Publishing

- Mahfi Eğilmez, (29.09.2013), “Cari Denge Geometrisi”, Kendime Yazılar $<$ http://www.mahfiegilmez.com/2013/09/cari-denge-geometrisi.html Erişim Tarihi:15.08.2015

- Öztürk, N. (2011) "Para, Banka ve Kredi” Ekin Basın-Yayım, Sivas

- Seyidoğlu, H. (2009) "Uluslararası İktisat" Geliştirilmiş 17. Baskı,Güzem Can Yayınları, İstanbul

- TCMB, (2005) “Türkiye Cumhuriyet Merkez Bankası'nda Döviz Rezervi Yönetimi” http://www.tcmb.gov.tr/

- TCMB, Elektronik Veri Dağıtım Sistemi, http://evds.tcmb.gov.tr/ 
- TİM, (2014) “Ekonomi Ve Dış Ticaret Raporu” Türkiye İhracatçılar Meclisi

- TÜIKK, Türkiye İstatistik Kurumu, http://www.tuik.gov.tr/

- UNCTAD, United Nations Conference On Trade And Development http://unctadstat.unctad.org

- Yalçıner, K. (2012) “Uluslararası Finansman” Detay Yayıncılık, Ankara 